\title{
DYNAMIC PRODUCTS IN WORLD EXPORTS
}

Jörg Mayer, Arunas Butkevicius and Ali Kadri

No. 159

May 2002

\section{DISCUSSION PAPERS}




\title{
DYNAMIC PRODUCTS IN WORLD EXPORTS
}

\author{
Jörg Mayer, Arunas Butkevicius and Ali Kadri
}

No. 159

May 2002

This study was prepared as a background document for the Trade and Development Report 2002. The empirical analysis for the study was completed in December 2000. The authors are grateful to Yilmaz Akyüz, William Choa, Detlef Kotte and Robert Rowthorn for helpful comments and suggestions on an earlier draft. The opinions expressed are those of the authors and do not necessarily reflect the views of UNCTAD. 
The opinions expressed in this paper are those of the author and do not necessarily reflect the views of UNCTAD. The designations and terminology employed are also those of the author.

UNCTAD Discussion Papers are read anonymously by at least one referee, whose comments are taken into account before publication.

Comments on this paper are invited and may be addressed to the author, c/o the Publications Assistant*, Macroeconomic and Development Policies, GDS, United Nations Conference on Trade and Development (UNCTAD), Palais des Nations, CH-1211 Geneva 10, Switzerland. Copies of Discussion Papers may also be obtained from this address. New Discussion Papers are available on the website at: http.//www.unctad.org/en/pub/pubframe/htm

* $\quad$ Fax: (4122) 907 0274; E-mail: mdpb-ed.assistant@ unctad.org 


\section{CONTENTS}

Page

Abstract

Introduction

I. Identification of dynamic products in world exports

A. A survey of all products ............................................................................. 3

1. Average annual export value growth during the period 1980-1998............... 3

2. Composite measures of export dynamism................................................ 5

3. Predictability of export-value growth ................................................. 6

4. $\quad$ Market-share concentration in specific product markets ............................ 7

5. Summary and conclusions ................................................................... 8

B. An analysis by product categories ................................................................. 9

1. Product categories by factor intensity .................................................. 9

2. Product categories by long-run productivity growth in large developed countries.................................................................. 11

3. Product categories by main factor affecting the competitive process ............ 12

4. Summary and conclusions ........................................................... 13

II. Dynamic products in trade of regional groups and selected developing countries............. 14

A. The most dynamic products in the exports of regional groups ............................ 14

B. Dynamic products and the export composition of selected developing countries..... 16

C. Trade flows of the most dynamic export products................................................ 17

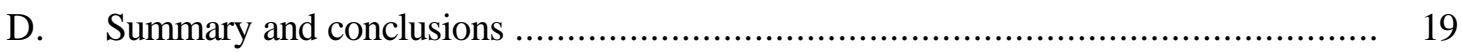

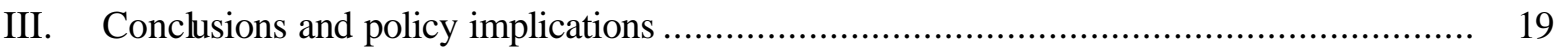

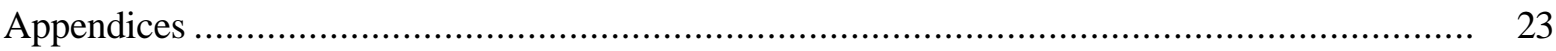

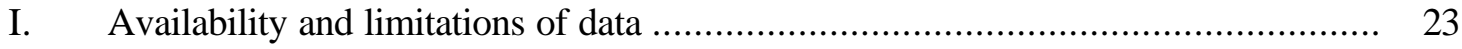

II. Description of statistical and econometric methods......................................... 24

III. Definition of product categories.................................................................. 27

1. Product categories by factor intensity .............................................. 27

2. Product categories by main factor affecting the competitive process............. 28

3. Agricultural goods which are high-value products and/or items with an income elasticity of demand greater than one ................................ 29

4. By long run growth of total factor productivity in large developed countries... 29

Figures and tables

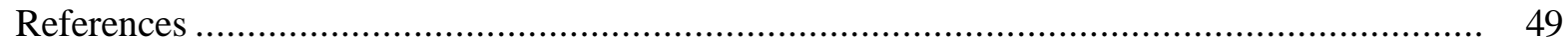




\section{List of figures and tables}

\section{Figure}

1a Growth of world non-fuel exports of different product categories by factor intensity......... 31

$1 \mathrm{~b}$ Structure of world non-fuel exports by product category according to factor intensity, 1980-1998

1c Growth of developing country non-fuel exports of different product categories, by factor intensity

1d Structure of developing country non-fuel exports by product category according to factor intensity, 1980-1998.

2a Export dynamism of internationally traded non-fuel products, by factor intensity.....

$2 \mathrm{~b}$ Export dynamism of internationally traded non-fuel products, by main factor affecting the competitive process

3a Growth of world non-fuel exports of different product categories, by main factor affecting the competitive process

$3 \mathrm{~b}$ Structure of world non-fuel exports by product category according to main factor affecting the competitive process, 1980-1998.

$3 c$ Growth of developing country non-fuel exports of different product categories, by main factor affecting the competitive process

3d Structure of developing country non-fuel exports by product category according to main factor influencing the competitive process, 1980-1998

4a Dynamism of developing country non-fuel exports, by factor intensity

$4 \mathrm{~b}$ Dynamism of developing country non-fuel exports, by main factor affecting the competitive process

\section{Table}

1a The 20 most dynamic products in world non-fuel exports, ranked by average annual export value growth, 1980-1998.

$1 \mathrm{~b}$ The 20 most dynamic products in world non-fuel exports, ranked by average annual export value growth, 1996-1998.

2 Shares of main exporters, developed and developing countries in world non-fuel exports of the 20 most dynamic products (ranked by index of dynamism based on export values, 1980-1998), 1998

3 The 20 most dynamic products in world non-fuel exports, ranked by index of dynamism based on shares in total exports, 1980-1998

4 Predictability of annual export value growth, selected products, 1980-1998.

5 The 20 most dynamic products in world non-fuel exports ranked by composite index on predictability, volatility and growth, 1980-1998

6 Market-share concentration of dynamic products in world non-fuel exports identified on basis of index of dynamism, based on export values, 1980-1998

7 Shares of main exporters, developed and developing countries in world exports of the most dynamic agricultural commodities (ranked by index of dynamism based on export values, 1980-1998), 1998

8 Leading dynamic products by exporting region, ranked by average annual export value growth, 1980-1988

9 Composition of non-fuel exports, selected developing countries, 1996-1998 averages......

10 Dynamic products in non-fuel imports of developing countries, by average annual import value growth, 1988-1998 


\title{
DYNAMIC PRODUCTS IN WORLD EXPORTS
}

\author{
Jörg Mayer, Arunas Butkevicius and Ali Kadri
}

United Nations Conference on Trade and Development

\begin{abstract}
The values and market shares of three product categories have grown most rapidly in world exports during the period 1980-1998: electrical and electronic goods (including parts and components for such goods), goods which require high $R \& D$ expenditures, and labour-intensive products, particularly clothing. A strong geographical concentration in developing countries at both regional and country levels is discernable regarding the origin of these products. There appears to be a sustained movement in world exports towards the growing significance of a limited number of products and it would seem that there has been a rapid and sustained technological upgrading in the export composition of developing countries. However, since the involvement of developing countries is usually limited to the labour-intensive stages in the production process of technologyintensive goods in the context of international production sharing, simple measures of growth in gross export values are poor guides for an assessment of the nature of participation of developing countries in world trade.
\end{abstract}

\section{INTRODUCTION}

The rate of growth in the value of international trade has been strong and since the mid-1980s has consistently exceeded that of world output. As is well known, this is linked to the increasing integration of national economies into world trade, the deepening of the international division of labour and the concomitant emergence of increasingly internationalized production patterns. These developments have greatly increased the difficulties of monitoring trade performance with a view to providing appropriate trade policy support.

The key objective of this study is to identify options available to policy makers in developing countries in their strategic approaches towards the integration of their countries into the international trading system with a view to promoting development. While trade integration in general can bring about substantial efficiency gains and lead to better communication and trading networks, imports and exports play distinct roles in this process. A number of recent studies have emphasized imports as a carrier of knowledge and shown that developing countries with rapid growth in total factor productivity have imported more from the world's technology leaders. On the export side, emphasis has been on benefits deriving from specialization according to comparative advantage and from the exploitation of increasing returns from larger markets. These contributions have usually looked at exports in general, ignoring the importance of specific products on which the export drive is based. However, to the extent that a developing country can concentrate its exports on what may be called 'dynamic' products, it will be able both to limit the risk that its export markets will become rapidly saturated as a result of more and more countries concentrating their export drives on the same products, and to exploit the potential for long-term productivity growth associated with an exportoriented industrialization strategy. 
Satisfying the dual policy goals of limiting the risk of an export product's becoming subject to the 'fallacy of composition' and maximizing the developmental impact of the chosen export strategy requires different definitions of 'dynamic products'. For the first goal, dynamism can be defined on the basis of past average export value growth of a specific product. This is a purely statistical measure that treats all products equally irrespective of differences with regard to the impact of their production and exports on overall development and the potential for long-run productivity growth. The second goal requires defining dynamism in a way that reflects sectoral differences in skill and technology intensity. For this purpose, products can be grouped according to (i) differences in factor intensity regarding technology, capital, and skilled labour, or (ii) long-run rates of sectoral productivity growth which have been observed in large developed countries. Products can also be classified (iii) according to the main factor that affects the competitive process (such as factor intensity, scale of production, product differentiation, etc) in order to assess the main type of economic benefits that can be derived from exporting such products.

It needs to be noted that the results of any analysis of export dynamism are sensitive to the time period chosen. Given that export data at the low level of aggregation used in this paper are available only on an annual basis and that the methodological tools used to analyse these data require long-time series in order to obtain reliable estimates, the analysis has been based on a long-term perspective, namely the period between 1980 and 1998. This period is the longest one for which reliable export data are available. However, this long-run perspective will be supplemented by indicators based on developments during the 1990s as necessary in order to put the results of the longrun analysis into proper perspective. It should also be noted that the data source used for this study (i.e. mainly COMTRADE ${ }^{1}$ ) reports trade in a comprehensive way only in value terms, with volumes available only for a small number of items (mainly primary commodities). As a consequence, the analysis could be conducted only on the basis of trade values.

The structure of the study is as follows. Section I takes a product-specific perspective and analyses the evolution of the export values (in terms of current US dollar) of 225 products (see Appendix I for discussion on which products are excluded) from 234 developed and developing countries and territories, and economies in transition, i.e. all countries and territories for which data are available in the United Nations' COMTRADE database. The section first looks at trend growth over the 1980-1998 period and relevant composite measures which are also applied to growth during 1996-1998 (to capture developments associated with the East Asian crisis ${ }^{2}$, as well as possible dynamics following the beginning of the staged implementation of the Uruguay Round concessions); it then examines the stability of trend growth and product share in global exports and looks at the

\footnotetext{
${ }^{1}$ United Nations Department of Economic and Social Affairs (UN/DESA), Commodity Trade Statistics database.

2 Duttagupta and Spilimbergo (2000) show that the growth rate of export earnings of East Asian economies (including Hong Kong (China), Indonesia, Republic of Korea, Singapore, and Thailand), i.e. developing economies that are among those whose export earnings have grown most over the past three decades or so, started to decline in 1995, with export earnings basically stagnating during 1996 and 1997 and declining in 1998 . They also show that this decline in export earnings was specific to East Asia and cannot be explained by worldwide demand factors.
} 
predictability of export value growth; section I finally analyses the export experience of specific product categories. Section II first takes a country-specific perspective and examines the export experience of regional groups and selected developing countries to delineate the extent to which they have succeeded in keeping pace with changes in world trade. The last part of section II looks at the direction of trade flows in an attempt to explain why certain products have followed a more dynamic export pattern than others and briefly discusses the role of preferential tariff provisions for international production sharing, particularly at the regional level. Section III discusses policy implications of the findings. Discussions of data availability and their limitations as well as the definitions of statistical measures and product categories are in the Appendix.

As such, the study complements existing work on dynamic products in world exports undertaken by UNCTAD (2000, Table 4.3; and 1997] and Lall (1998, 2000), or the estimations included in the TradeMap analysis tool of the International Trade Centre UNCTAD/WTO as discussed in ITC (1999), and in TradeCAN of UNECLAC and the World Bank (1999).

\section{IDENTIFICATION OF DYNAMIC PRODUCTS IN WORLD EXPORTS}

\section{A. A survey of all products}

\section{Average annual export value growth during the period 1980-1998}

Various measures can be used to define the dynamism of a specific product's evolution in global exports over time, including the rate of growth over alternative periods, the degree of growth stability, and changes of a product's share in total exports. The results based on these measures, however, are not necessarily consistent, as can be seen by comparing table 1a which ranks the products according to the average rate of annual export value growth during the period 1980-1998, and table $1 \mathrm{~b}$ where ranking is based on growth during the last three years of this period, i.e. 19961998. ${ }^{3}$ Of the 20 products that are identified as the most dynamic products during the longer period, only four (optical instruments, knitted under garments, telecommunications equipment, and medicinal and pharmaceutical products) appear also on the list of the 20 most dynamic products during 1996-1998.

Most of the fastest growing products listed in tables 1a and 1b broadly fall in four groups, namely (i) electrical and electric goods (Standard International Trade Classification (SITC) 75-77) including parts and components for such goods, (ii) textiles, and labour-intensive manufactures, in particular clothing (SITC 61, 65, and 84), (iii) finished products from industries which require high R\&D expenditures and are characterized by high technological complexity and/or a high degree of economies of scale in particular at the firm level (SITC 5; 7 less 75-77; 87), and (iv) primary commodities. As will be shown below, strong growth in the export value of products in the first three groups is most likely a reflection of the deepening of the international division of labour which has given rise to increasingly internationalized production networks, while strong growth in the export value of primary commodities tends to reflect specific developments in one or a small number of exporting countries.

\footnotetext{
${ }^{3}$ The correlation coefficient between the series on growth during 1980-1998 and that during 1996-1998 is 0.29.
} 
It may be worthwhile addressing briefly the main determinants of international production sharing and of the strong growth in the export value of specific primary commodities. International production sharing can occur at the vertical or horizontal level. Vertical international production sharing ${ }^{4}$ has been stimulated by a reduction in communication and transportation costs and has generally been concentrated in labour-intensive activities. Such activities often regard production processes that are at a relatively low level of technology (such as in clothing), but they can also be labour-intensive parts of generally technologically complex production processes (such as in electronics or in parts of the automotive industry). Labour-intensive production processes are spread over production sites located in different countries if doing so allows producers to take advantage of differences in technologies and factor prices among countries and, thereby, to reduce costs. In the textiles and clothing industry, for example, the pre-assembling phases of the production process have become more capital intensive due to growing automation, while the assembling stages have remained relatively labour intensive. As a result, it has become both technically and economically convenient to relocate abroad the assembling segments of production alone and to re-import the final apparel products (see, e.g., Gereffi, 1999). Such outward processing trade in the textiles and clothing industry has benefited from favourable regulations (see section II.C), which were adopted by the United States and the European Union at least partly in order to maintain the competitiveness of their domestic textiles and clothing industries. Whereas items in the textiles and clothing sector represent an important part of vertical international fragmentation of production, there is evidence suggesting that a substantial part of trade in chemicals, the automotive industry and in the electronics industry is also due to vertical production sharing (Hummels, Rapoport and Yi (1998)). The increasing international division of labour in the latter sector is reflected in the vastly growing importance of trade in parts and components for electrical and electronic goods.

Regarding the importance of vertical international production sharing, Hummels, Ishii and Yi (2001) use input-output tables from the OECD and emerging market countries and estimate that trade based on vertical specialization accounts for up to 30 per cent of world exports and that it has grown by as much as 40 per cent in the last twenty-five years. Yeats (2001) and Ng and Yeats (2001) explain that it is very difficult to trace the size of vertical international production sharing at the global level because international trade classifications prior to the second revision of SITC did not allow for making the distinction between trade in final goods and trade in parts and components. In spite of the revision, making this distinction is still not possible to a sufficient degree except for the group 'machinery and transport equipment' (SITC 7) which, however, accounts for approximately half of world trade in manufactures. According to Yeats (2001), trade in parts and components is highly concentrated in parts of motor vehicles (SITC 784), parts of computers and office machines (SITC 759), telecommunications equipment and parts (SITC 764), and electrical apparatus and switches (SITC 772). Ng and Yeats (2001) show that trade in transistors and semiconductors (SITC 776) have played an important role in production sharing in East Asia. The fact that the importance of trade in

\footnotetext{
4 The phenomenon has alternatively been referred to as outsourcing, de-localization, fragmentation, intraproduct specialization, intra-mediate trade, vertical specialization, and slicing the value chain but generally means the geographic separation of activities involved in producing a good (or service) across two or more countries. For a discussion of various issues associated with vertical international production sharing see, for example, Arndt and Kierzkowski (2001).
} 
parts and components has strongly increased over the past few years and that parts and components from the electronics industry account for an important part of such trade overall, suggests that the rapid development of global production sharing in electrical and electronic goods has been a crucial determinant of the dynamic growth performance of these products, as reflected in table 1a.

Horizontal international production sharing involves the geographical dispersion of production of similar products, which differ mainly in terms of variety. Trade based on horizontal international production sharing occurs mainly between developed countries which have similar resource combinations and which are geographically close but it can also be observed between developing countries which are part of regional trade agreements such as MERCOSUR and ASEAN. Growth in this kind of trade has been driven mainly by attempts to raise economies of scale in particular at the firm level and has resulted in a higher degree of specialization in production and trade. The automotive industry is a standard example of a sector for which horizontal international production sharing has occurred but anecdotal evidence suggests that sectors such as the chemical and pharmaceutical industry, aerospace and other transport equipment, as well as the specialized machinery industry, have also been affected.

A somewhat unexpected result with regard to the growth of total export values during the period 1980-1998 is that three out of the top 20 products are primary commodities (silk, non-alcoholic beverages, and cereals), as can be seen from table 1a. However, these primary products have a low share in world exports (column 3), suggesting that their strong growth is due at least partly to the fact that they started from a low base. The growth rate of silk exports during 1980-1998 also has a very low degree of stability (column 4$)^{5}$ and silk ranks close to the bottom with regard to export value growth during 1996-1998 (column 5). Close inspection of the data reveals that the strong growth of silk exports between 1980 and 1998 is largely attributable to the fact that China has been a major exporter of silk and that China's trade data became available on an internationally comparable basis only in the mid-1980s. Table 1b shows that during 1996-1998 seven out of the 20 most dynamic products were primary commodities. However, the above observations as to growth stability and share in world exports also apply to these products. Taken together, the above results suggest that contrary to what has often been argued export values of primary products can experience strong growth rates. It is true, however, that rapid export growth of primary commodities has often been short-lived and relied on particular developments in one or a small number of exporting countries. ${ }^{6}$

\section{Composite measures of export dynamism}

To overcome the difficulties in identifying export dynamism on the basis of a single measure, a composite measure is constructed which tries to incorporate individual measures in a meaningful way. Table 2 lists the 20 most dynamic products identified on the basis of a combined measure derived

\footnotetext{
5 Stability is measured as the inverse of volatility around the trend of growth during 1980-1998; see Appendix II.

6 For example, the rapid growth of silver and platinum exports during 1996-1998 is entirely due to a massive increase in registered exports from the Russian Federation between 1997 and 1998, while the strong growth rate of tea exports during 1996-1998 reflects almost exclusively strongly increased exports by the two leading exporting countries, Kenya and India.
} 
by using factor analysis (see Appendix II for details) which may be called a comprehensive index; it includes the rate of growth in export value during 1980-1998, the volatility of this growth rate, the rate of growth in export value during 1996-1998, and the average share of a product in total world exports during 1980-1998. The results give support to those based on the single measure of export dynamism referring to the period 1980-1998 (table 1a, column 1): four out of the top five products are electrical and electronic goods (including parts and components for such goods), and five out of the top ten and nine out of the top 20 products are finished goods which require high R\&D expenditure. Again similarly to the results on the single measure of export dynamism during the period 1980-1998, several product groups from the textiles and clothing industry are among the most dynamic ones, occupying the ranks 10,21, 23, 24 and 25. By contrast, on the composite measure no primary commodity ranks among the most dynamic products.

Table 2 also identifies the share of developed and developing countries taken as groups, as well as that of the main individual exporters, in total world exports of these 20 most dynamic products in 1998. As expected developed countries account for some 90 per cent of the total export value in nine products which require high $R \& D$ expenditures and are characterized by high technological complexity and/or a high degree of economies of scale particularly at the firm level. Only in optical instruments and apparatus do developing countries account for about 30 per cent of the total export value. In comparison, the share of developing countries in the total export value of part and components for electrical and electronic goods is about 40 per cent, while for telecommunications equipment and parts (SITC 764) and electric apparatus and switches (SITC 772) it is about one fourth of the total value. The only product from the textiles and apparel industry (under garments (SITC 846)) that ranks among the 20 most dynamic products is also the only one for which the share of developing countries in world exports exceeds that of developed countries.

It can be argued that the growth rate of a product's share in world exports is a more appropriate measure of dynamism than the corresponding rate based on export value. This is because a given increase in absolute value translates into a higher growth rate for a product with a lower initial share than for one with a higher initial share. This means that rapid growth in value terms could simply reflect a low base in 1980. Table 3 ranks the product groups according to a measure based on 1980-1998 aggregates that may be called a share index. In each product, it incorporates the linear growth rate of its share in world exports, the volatility of this growth rate, and its period average share in world exports. This measure gives essentially the same results as those based on export values reported in tables $1 \mathrm{a}, 1 \mathrm{~b}$ and 2 . Accordingly, the most dynamic product groups identified on the basis of average annual export value growth are not those with small shares in world exports in 1980.

\section{Predictability of export-value growth}

An unforeseen drop in export earnings has adverse impacts on the country's current-account balance and can impair import capacity and jeopardize the attainment of growth targets. For exporters, unforeseen earnings variability increases uncertainty regarding both cash flows, and hence borrowing 
costs, and the profitability of investment. It is therefore important to assess the predictability of export value growth (see Appendix II for details on how predictability is measured).

Table 4 shows that products for which export value growth can be best predicted are also among those which rank high in terms of both growth in average export shares and the composite index based on values. ${ }^{7}$ By contrast, the vast majority of those products for which export value growth are least predictable also rank low in terms of these two measures. Manufactures, in particular those finished goods that are most likely to have been subject to horizontal international production sharing (and are exported mostly by developed countries), feature prominently in the top ranks of predictability, while most bottom ranks are occupied by primary products. However, it is also interesting to note that among primary commodities, export value growth for fresh fish and fresh meat can be predicted relatively well. Many developing countries have an export potential for these products and - as shown in the last column of table 4 - the share of these product groups in total world non-fuel exports has grown faster than that of most other primary commodities.

Given the apparent close relationship between predicted and actual average export value growth, it may be worthwhile constructing an index that combines predictability, volatility and actual growth of export values during the period 1980-1998. The results of this exercise, shown in table 5, indicate that the majority of the products which share the characteristics of rapid, predictable and stable rates of growth in export values are among the most dynamic products on the composite indices in terms of either export values (table 2 ) or shares in total world exports (table 3 ). ${ }^{8}$ This suggests that, compared to the other products, the products whose export values have grown most over the past 20 years have experienced a sustained and relatively smooth pattern of growth, rather than experiencing a boom and bust cycle.

\section{Market-share concentration in specific product markets}

The ease with which exporters from developing countries can enter the world market for a specific product depends on a wide range of factors. One such factor is the degree of market concentration. Where barriers to entry are low competition has a tendency to drive supply up, and prices and profits down. By contrast, where barriers to entry are high - be it because the product is the result of innovation and technological progress so that competition is on quality rather than on price, or because of oligopolistic market structures resulting from stringent requirements regarding design, branding, or marketing - increasing export quantities will not affect prices but instead lead to rising export revenues. Off hand, it would seem that within the manufacturing sector barriers to entry in labour-intensive products may be relatively low because unit-labour costs and price-based competition are more important than in other manufactured products where innovation and hence quality-based competition are of greater relative importance. However, this is not necessarily the case. In the textiles

\footnotetext{
7 This result also suggests that there is no product whose export value stagnated throughout the 1980-1998 period because such a product would be predictably best and hence rank at the top.

8 Nine of the products that are ranked among the top 20 on the composite index on either values or shares are not among the top 20 on this combined measure. However, in each case six out of the nine products are among the top 40 on the combined measure.
} 
and clothing industry, for example, relocation of the labour-intensive assembling stages often takes place only if the final consumer perceives that the firm that originates outward processing still retains control over product quality, for instance, through the persistence of the original national brand.

Market-share concentration during the period 1980-1998 (see Appendix II for the definition of the index) is shown in table 6 for the 20 most dynamic products on the basis of the value-related index of dynamism (table 2). Table 6 shows that export market shares for all the 20 products (except knitted undergarments) have become more equally distributed; this suggests that entering the markets for these most dynamic products have become easier. As an explanation, the fact that the export values of these products have grown most rapidly may have acted as a powerful incentive for other producers to export these products. However, the more likely explanation is that (i) export market shares in technology-intensive products, such as aircraft, have become more equally distributed due to growing intra-industry trade, and that (ii) export market shares in product groups such as transistors and semiconductors, computers, telecommunications equipment and parts, and clothing have become more equally distributed because of the growing importance of vertical international production sharing, which has allowed specific labour-intensive activities to be carried out in countries which had previously not been able to export such products.

Ranking manufactured products according to the index numbers for 1997-1998 (not shown) reveals that - in addition to products from the iron and steel sector (SITC 67) - export market shares are most equally distributed for product groups from the textiles and clothing sector (SITC 65 and 84), eight of which rank among the 20 products with the most equal market distribution. By contrast, product groups from the machinery sector as well as transport equipment (such as aircraft, ships and boats, and passenger motor vehicles) are among those for which market concentration is highest.

\section{Summary and conclusions}

To summarize, three product groups have been identified as those whose export values and market shares have grown most rapidly and whose growth rates have been least volatile: electrical and electronic goods (including parts and components for such goods), goods that require high R\&D expenditures and that are characterized by high technological and managerial complexity, and labourintensive products in particular clothing. These are also the products found in earlier studies to have been affected most by two phenomena of the world trading system that have rapidly gained in importance over the past few years, namely the horizontal and vertical fragmentation of production processes at the international level. Various primary products have also experienced strong export value growth but their growth performance has been marked by considerable volatility and has often been attributable to specific circumstances in a few exporting countries. Products whose export value development can be best predicted are also those which have experienced the most rapid growth and which have a relatively high average share in world exports. This suggests that there has been a sustained movement in world exports towards the growing significance of a limited number of products. 


\section{B. An analysis by product categories}

\section{Product categories by factor intensity}

The effects on development of specific products differ according to the extent of linkages provided by their production and exports especially in terms of industrial upgrading. The latter is a process of improving the ability of a firm or an economy to move to more profitable and/or more skilland technology-intensive economic activities. It is generally considered that the potential for long-run productivity growth through deepening and diversification in the primary sector are limited. Thus, to the extent that underlying factor combinations offer this possibility, developing countries need to shift the structure of economic activity away from resource-dependent and labour-intensive activities towards technology, scale and skill-intensive activities in order to achieve rapid and sustained economic growth. Clearly, to achieve such a shift developing countries need to overcome a number of constraints, including the scarcity of physical and human capital, lack of specialized technical knowledge and narrow domestic markets. Accordingly, policies that foster the accumulation of physical and human capital and improve access to foreign technology are critical parts of industrial upgrading in developing countries.

A classification of products according to linkages between industrial upgrading and exports can be based on differences in factor intensity regarding skill, technology, and capital (see Appendix III.1 for details on the composition of the product categories). Such a classification results in five product categories, namely non-fuel primary commodities, labour- and resource-intensive manufactures, low skill- and technology-intensive manufactures, medium skill- and technologyintensive manufactures, and high skill- and technology-intensive manufactures. The results of an analysis of variance (see Appendix II for explanation) suggest that export value growth over the period 1980-1998 differs between the five product categories in a statistically significant way at conventional confidence levels, both for world exports and exports from developing countries. This suggests that forming these different categories is meaningful also from a statistical point of view.

With regard to world non-fuel trade, figure 1a shows that export values of all five product categories started to grow rapidly in the mid-1980s. However, export value growth of the high skilland technology-intensive category was strongest throughout the period 1980-1998, with the growth difference to the other product categories strongly increasing after 1993. The absolute export value of this category grew about fivefold between 1980 and 1998. Export values of the labour- and resourceintensive category, as well as of the medium skill- and technology-intensive product category, have also grown faster than that of total non-fuel exports but the difference has remained fairly small. By contrast, export values of the low skill- and technology-intensive category and, in particular, of nonfuel primary commodities have grown much slower than total non-fuel exports. The impact of these differences in export value growth of the different product categories on their respective shares in world non-fuel exports is shown in figure 1b. Most notable are the strong and sustained drop in the share of non-fuel primary commodities, and the strong and sustained increase in the share of the high skill- and technology-intensive category. The latter now accounts for the highest share in world nonfuel exports among all five product categories. 
Regarding non-fuel exports from developing countries, figure 1c shows that export values of all product categories have grown more rapidly than the same category in world exports and that this difference has been higher the more skill- and technology-intensive is the product category: 14-fold for the high, 11-fold for the medium, and about 7-fold for the low skill- and technology-intensive product category. The group of non-fuel primary commodities is the only product category whose export value has grown less than total non-fuel exports from developing countries. Figure 1d shows that this difference in export value growth has led to a steep fall in the share of non-fuel primary commodities in total non-fuel exports from developing countries (from over 50 to under 20 per cent). In addition, the share of the labour- and resource-intensive category, as well as that of the low skilland technology-intensive category, has over the whole period remained largely unchanged, while the share of the medium and, in particular, of the high skill- and technology-intensive category has strongly increased. Since the mid-1990s, the group of high skill- and technology-intensive manufactures has in fact had the highest share in total developing country non-fuel exports.

The question arises as to whether the rate of growth of a specific product group has been equally based or driven by specific individual product groups within each category. Based on the Standard International Trade Classification (SITC) at the 2-digit level (a few products refer to items at the 3-digit level as shown in Appendices III.1 and 2, forty-six product divisions have been formed. The right-hand side of figures $2 \mathrm{a}$ and $2 \mathrm{~b}$ shows that goods from all product groups have experienced rapid export value growth. By contrast, looking at both sides of the figures together reveals that rapid growth has been combined with large market shares only for products from the high- and the mediumskill and technology categories in figure $2 \mathrm{a}$, and from the scale-intensive (associated with vertical production sharing) and the specialized-supplier (associated with horizontal production sharing) categories in figure $2 b$.

Not all developing countries have the necessary factor combinations that would allow them to opt for rapid industrial upgrading. As in manufactures, primary products also differ in their developmental potential. For example, a number of unprocessed and processed agricultural products (including (i) meat and meat products, (ii) dairy products, (iii) fish and fishery products, (iv) vegetables, (v) fruits and nuts, (vi) spices, and (vii) vegetable oils; see Appendix III.3 for details on this product classification) are high-unit-value products and/or products with an income elasticity of demand greater than one, and much higher than for traditional agricultural products. Exporting products in this category of agricultural commodities offers opportunities for adding value and for skill- and technology-intensive activities. The quality and logistics requirements of these products are in some respects more typical of modern manufacturing industry than those of traditional agricultural products. This is because standards of product quality, safety and consistency, delivery, packaging, and speed and reliability of supply are much higher than, for example, for basic food commodities. There is at least one item in each of the seven product groups, except dairy products and spices, whose value of exports from developing countries now exceeds that of traditional primary commodities such as cereals, cocoa, tea or natural rubber. Moreover, rapid expansion of exports from these sectors has contributed to growth in agricultural GDP and total food production in a number of developing 
countries, such as Brazil, China, and Thailand, as well as to rapid GDP growth, for example, in Chile and Israel (Jaffee and Gordon, 1993; World Bank, 1994, p. 39).

Table 7 shows that this set of products has been more export dynamic than most other agricultural primary commodities. Twelve out of the seventeen products are among the 25 most dynamic agricultural products in world exports, as measured by the index of dynamism based on export values over the period 1980-1998. Moreover, these twelve products cover all of the seven product groups. The table also shows that the share of developing countries in world exports in much higher for most of these 12 products than it is for other agricultural products.

\section{Products categories by long-run productivity growth in large developed countries}

The above classification based on different skill- and technological intensities reflects common perceptions regarding different skill- and technological intensities in the production of products. Assuming that an increased use of human capital and technology in production favourably influences productivity, this classification gives a rough indication of sectoral differences in terms of the potential for productivity growth. However, it is clear that (i) high productivity - value-added per worker - is not synonymous with high skill and technological intensity in production, and (ii) productivity is influenced by a number of factors in addition to the use of human capital, physical capital and technology in production.

High value-added per worker usually occurs in sectors that are highly capital-intensive or in traditional heavy manufacturing sectors, while it is often lower in sectors that are highly technologyintensive. For example, in 1999, value added per worker in the United States was substantially higher in cigarette manufacturing, petroleum refineries, and automobile manufacturing $(1,944,000 ; 551,000$; and 308,000 US dollars, respectively) than in aircraft manufacturing (170,000 US dollars) or in computer and electronic product manufacturing (167,000 US dollars). ${ }^{9}$

Labour productivity is determined by a complex array of factors. In the context of this study, two factors may be of particular interest with respect to the above observation that value-added per worker in production does not always correspond to technology intensity in production. New management and organizational techniques, for example, can lead to very substantial productivity increases in specific industrial sectors. One illustration of this is the lean production system that conferred a substantial advantage to Japanese automobile manufacturers over their competitors that continued to rely on the Fordist system. Another example is linked to the debate on the sources of the growth in labour productivity in the United States during the second half of the 1990s. Some observers concentrate on the contribution of information technology to productivity growth solely stemming from the production of computers and semiconductors, while others emphasize the large benefits that actually accrue from the use of information technology. ${ }^{10}$

\footnotetext{
9 U.S. Census Bureau, 2001. Statistics for Industry Groups and Industries. Annual Survey of Manufacturers. (U.S. Department of Commerce: Washington, DC). http://www.census.gov/prod/2001pubs/m99-as1.pdf.

10 On these different views see Oliner and Sichel (2000) and Gordon (2000).
} 
Total factor productivity (TFP) is an alternative concept to labour productivity in choosing an indicator for productivity and measuring the link between technology intensity and economic

performance. Choudhri and Hakura (2000) have estimated sectoral long-run rates of TFP growth in large developed countries that can be considered technological leaders. According to this study, the sectors with the fastest TFP growth are, in terms of the International Standard Industrial Classification (ISIC): textiles, apparel and leather products; chemicals and chemical products; and fabricated metal products, machinery and equipment (including computers, and transistors and semiconductors). The definition of these ISIC sectors differs from that of SITC product groups that is usually applied in trade analyses. Nonetheless, the majority of the SITC product groups identified above (table 1a) as the most dynamic in world exports fall into the category of ISIC manufacturing sectors with high TPF growth, the exceptions being the three primary commodity groups (silk, non-alcoholic beverages, and cereals), and musical instruments and records.

\section{Product categories by main factor affecting the competitive process}

The above classification by factor intensity may lead to the conclusion that striving to export the most technology and skill-intensive products is economically desirable in itself to the exclusion of considerations relating to a country's underlying factor combinations. To overcome this weakness, consider an alternative classification based on the primary factors that are believed to affect the competitive process in each activity (see Appendix III.2 for details on the composition of the product groups). Such a classification also provides a link between the way product groups are defined and the main types of economic benefits derived from their exports. For example, exporting scale-intensive goods allows firms to reduce costs by extending plant size and lengthening production runs, while exporting science-based products allows them to spread the high fixed costs associated with research and development over a larger market. The results of an analysis of variance suggest that average annual export value growth over the period 1980-1998 differs between the six product categories in a statistically significant way at conventional confidence levels, both for world exports and exports from developing countries. This suggests that forming these categories is meaningful also from a statistical point of view.

Export value growth performance of the six product categories is shown in figure $3 \mathrm{a}$ for nonfuel world exports and in figure $3 \mathrm{c}$ for non-fuel exports from developing countries. The science-based category recorded the strongest rate of export value growth between 1980 and 1998 for both world exports and exports from developing countries, followed by the differentiated product category (i.e. products associated with specialized supplier networks). World exports of the science-based category grew about six-fold during this period compared to a 21 -fold increase in the value of this category's exports from developing countries. Figure $3 \mathrm{~d}$ shows that the share of the science-based category in total non-fuel exports from developing countries was very small in 1980, so that the category's rapid growth is partly explained by the fact that it started from a low base. However, given that computers and office equipment (SITC 75) is included in the science-based category and that an important item of this product division refers to parts and components (SITC 759), it is likely that the very rapid export value growth of science-based exports from developing countries reflects the increased 
importance of international production sharing. The same conclusion probably holds regarding the high rate of growth recorded for developing country exports of the differentiated product category, given that it includes two other (namely SITC 764 and 776) of the above mentioned main product groups referring to parts and components for electrical and electronic goods.

Using the same product divisions as in figures $2 \mathrm{a}$ and $2 \mathrm{~b}$, figures $4 \mathrm{a}$ and $4 \mathrm{~b}$ show that the sectors with a high share in total non-fuel exports from developing countries in 1998 tend to be those with rapid average annual export value growth during the period 1980-1998. This suggests that developing country exports tend to be increasingly concentrated in a few products including computers and office equipment, communications equipment and semiconductors, and clothing. All of these products involve labour-intensive production processes, suggesting that this process of concentration is, at least in part, due to the increased importance of global production sharing.

\section{Summary and conclusions}

The analysis of growth in exports of different product categories suggests that there are dynamic products in all categories, including some primary commodities. However, exports of products from the high skill- and technology-intensive category and from the science-based category have grown most rapidly over the past two decades. Almost all of the most dynamic export products are in the category of products with high TFP growth in large developed countries. Perhaps the most striking finding is that the higher the skill and technology contents of exports, the faster is the growth rate of exports of developing countries compared to growth in world trade.

However, this does not necessarily imply that there has been a rapid and sustained technological upgrading in the exports of developing countries. First, their rapid growth in exports of skill- and technology-intensive products started from a relatively small base in the early 1980s. Secondly - and more importantly - since the involvement of developing countries is usually limited to the labour-intensive stages in the production process of these goods in the context of international production sharing, simple measures of growth in gross export values are poor guides for an assessment of the nature of participation of developing countries in world trade. On the other hand, this result also suggests that changes in the global trading environment in the form of a growing importance of global production sharing offer new opportunities for export-oriented industrialization because there are now production processes in a wider range of industrial sectors where developing countries' integration into global and regional markets can act as a catalyst to industrialization and growth. However, making use of these opportunities requires that developing countries over time succeed in upgrading their involvement in global production sharing beyond mere labour-intensive activities toward more capital, skill and technology-intensive processes. 


\section{DYNAMIC PRODUCTS IN TRADE OF REGIONAL GROUPS AND SELECTED DEVELOPING COUNTRIES}

Whereas the preceding section focused on the global level, this section examines the extent to which the export performance of regional groups and selected developing countries has paralleled that of world exports. It, first, identifies the most dynamic products in the exports of regional groups and compares them with the most dynamic products in world exports (as reported in table 1a) and, second, looks at the export composition of the developing countries with the most rapid growth in total exports over the past 20 years.

\section{A. The most dynamic products in exports of regional groups}

Regarding the most dynamic products in exports from regional groups ${ }^{11}$, table 8 shows that the 15 fastest growing products of developed countries are among the 20 most dynamic products in world exports. Given the importance of developed countries in world exports, this suggests that changes in the export composition of developed countries have been a key determinant of differences in export value growth across individual product groups over the past 20 years. The table also shows, somewhat surprisingly, that items from the clothing sector are among the most dynamic products in the exports of developed countries (while they are not among the most dynamic products in the exports of developing countries, as shown below). However, this is likely to be just another example of the growing importance of production outsourcing from developed to developing countries.

Only eight out of the 20 most dynamic products in the exports of developing countries are also among the 20 most dynamic products in world exports, but these eight groups include the four fastest growing product groups in world exports. Pulpwood (SITC 246), occupying rank 21, is the most dynamic primary commodity in developing country exports. Similarly to developed countries, all of the 20 most dynamic products are in the category of high TFP growth in large developed countries. Moreover, 18 of the 20 most dynamic products are either in the medium skill- and technologyintensive category or in the high skill- and technology-intensive category. Combined with the fact that all of the 20 most dynamic products in developing country exports are manufactures, this reflects again the above finding which - taking the data at face value - suggests that there has been a rapid and sustained technological upgrading in the exports of developing countries. However, as mentioned above, this is largely due to the increased participation of developing countries in the labour-intensive segments of production of high-tech electronic goods in the context of international production sharing.

It is likely that the export performance of the entire group of developing countries is strongly influenced by the inclusion of the first-tier Newly Industrialized Economies (first-tier NIEs), i.e. Hong Kong (China), the Republic of Korea, Singapore and Taiwan Province of China. Although the three most dynamic products of the entire group of developing countries are also among the six most

\footnotetext{
${ }^{11}$ For the composition of the country groups, see UNCTAD, 2000, Handbook of Statistics, (United Nations:
} New York and Geneva). 
dynamic products of developing countries excluding the first-tier NIEs, the overall result for the latter group gives, indeed, a substantially different picture. Perhaps most striking is the greater importance of telecommunication, audio and video equipment (SITC 76), and the lower importance of chemicals and pharmaceutical products (SITC 5) among the most dynamic products in exports from developing countries excluding the first-tier NIEs. Another remarkable outcome is that transistors and semiconductors (SITC 776), i.e. the product group ranking first in world exports and fourteenth in exports of the entire group of developing countries, occupies as low a rank as number 49 when the first-tier NIEs are excluded from the group of developing countries.

It is perhaps surprising that only three of the 20 most dynamic products in world exports are among the 20 most dynamic products in the exports of the first-tier NIEs; these are computers (SITC 752), parts of computers and office machines (SITC 759) and optical instruments (SITC 871). But these three items rank first for the entire group of developing countries and are among the six most dynamic products for the group of developing countries excluding the first-tier NIEs. By contrast, five items from the chemical industry are among the 20 most dynamic products exported by the first-tier NIEs and finished items from the motor vehicle industry also rank comparatively high (SITC 783 occupies rank 3; 781 rank 7; and 782 rank 24). Textiles rank much higher than clothing (the first item from the clothing sector (SITC 84) occupies rank 142), suggesting that within the textiles and clothing sector, the first-tier NIEs have, over the years, succeeded in upgrading their exports from the comparatively labour-intensive clothing to the more capital, skill and technology-intensive textiles part of the sector.

Electrical and electronic goods including parts and components for such goods (with the exception of transistors and semiconductors), and telecommunication, audio and video equipment are the 2 most dynamic groups in the exports of the group of developing countries in Asia excluding West Asia, Central Asia, the first-tier NIEs and China. These two groups feature prominently also in the list of the most dynamic products in the exports from the ASEAN-4, comprising Indonesia, Malaysia, the Philippines and Thailand. But it is noteworthy that passenger motor vehicles are also among the 20 fastest growing exports from the ASEAN 4. The list of the most dynamic products in the exports from South Asia belong to a wide variety of product groups but the relative importance of items from the electronics sector is significantly lower than in the other sub-groups of developing countries in Asia. The absence of any item from the clothing sector is also notable.

As a group, countries in South America appear to be largely excluded from dynamic exports in world markets. Only two of the group's fastest growing export products are among the 20 most dynamic products in world trade: non-alcoholic beverages (SITC 111) and knitted textile fabrics (SITC 655). One possible explanation for this is that the region has remained isolated from global production sharing due to, for example, significant geographical distance from the developed countries which have been most active in global production sharing. Products that appear to have been subject to vertical global production indeed occupy comparatively low ranks among dynamic products in the exports from South America (e.g. SITC 845 ranks 13; 655 ranks 20; 764 ranks 23; 844 ranks 39; 846 ranks 52; 776 ranks 85; 752 ranks 129; and 759 ranks 210). Another possible explanation is that, 
on average, South America is a comparatively natural-resource-abundant region. Thus, it does not come as a surprise that countries in South America have strongly expanded their primary exports, i.e. the six most dynamic products are primary commodities and three other primary commodities are among the 20 most dynamic products. Regarding countries in Central America and the Caribbean, the wide and diverse range of product groups among the 20 most dynamic products makes it difficult to detect a meaningful pattern, due, in part, to the heterogeneity of countries in the region. ${ }^{12}$

To summarize, the above findings suggest that product-specific dynamism in world exports is driven by developed countries and by developing countries in Asia, both the first-tier NIEs and other developing countries in East Asia, while large parts of the other developing regions appear to be excluded from product-specific growth in world exports.

\section{B. Dynamic products and the export composition of selected developing countries}

Turning to the experiences of individual countries, table 9 compares the composition of exports averaged over the period 1996-1998 for the 20 developing countries and economies with the most rapid growth in total exports during the period 1980-1998 and with a total export value that exceeded US $\$ 5$ billion in $1998 .{ }^{13}$ With respect to the four fastest growing product groups in world exports, four results are noteworthy:

- $\quad$ Electrical and electronic goods including parts and components for such goods, i.e. the most dynamic products in world exports, are the leading export products in all four first-tier NIEs (among the four countries, they are of substantially less importance in the Republic of Korea), as well as in Malaysia, the Philippines and Thailand, and they play an important role also in China, Costa Rica and Mexico. By contrast, they are not among the leading export products either in Chile, Colombia, India, Morocco or Peru and they are of comparatively little importance in Argentina, Brazil, Tunisia and Turkey;

- Textiles, and labour-intensive manufactures, in particular clothing, are important in China, Costa Rica, India, the Republic of Korea, Mexico, Morocco, the Philippines, Thailand, Turkey, Taiwan Province of China and Tunisia. They are of less importance in Colombia, Indonesia, Malaysia and Peru, and they are not among the leading export products in Argentina, Brazil, Chile, and Singapore;

- Transport equipment, in particular passenger motor cars and other motor vehicles, is the only product division among the group of finished products from industries which require high $R \& D$ expenditures and are characterized by high technological complexity and/or a high degree of economies of scale in particular at the firm level that features among the leading

\footnotetext{
12 The results for North Africa and sub-Saharan Africa are not reported because they are strongly influenced by a few countries (Mauritius and Senegal for sub-Saharan Africa) and the fact that those products which have grown fastest are those for which no data were available for 1980, either because data were not recorded or because such products were actually not exported.

13 If only the first of these two criteria is used, a vastly different set of countries will be selected and include (misleadingly so in our judgment) a large number of very small countries such as Cambodia, Equatorial Guinea, Djibouti, Laos, Benin, Bhutan, Maldives, Lesotho, and the Seychelles.
} 
export products in the selected group of countries, and they play a role only in Argentina, Brazil, the Republic of Korea, and Mexico. It is well-known, however, that these exports reflect nationally grown production activities only for the Republic of Korea;

- $\quad$ Primary commodities and in particular the group of dynamic primary commodities are not among the leading export products in the first-tier NIEs and China; they are of some importance in India, Indonesia, Malaysia, the Philippines, Thailand, Tunisia and Turkey, and they play a very important role in the exports of a number of South American countries and Morocco.

Many country-specific factors, including size and resource endowments have undoubtedly influenced the export composition and dynamics of these countries. There is, however, a striking regional pattern in the different experiences of countries which suggests that geography has played an important role. Products that are involved in global production sharing are important only in the exports of countries which are geographically close to one of the main developed country markets, namely the United States, the European Union and Japan. By contrast, their role is of low significance in countries that are geographically distant from these markets, such as South American countries whose exports continue to be dominated by primary commodities. Moreover, there appears to be a division of labour within East Asia as far as the textiles and clothing sector is concerned, with enterprises in the Republic of Korea and Taiwan Province of China exporting textiles, whose production is comparatively more capital, skill and technology intensive, while enterprises in the other East Asian countries in table 9 concentrate on the more labour-intensive clothing sector.

\section{Trade flows of the most dynamic export products}

This section focuses on the direction of trade flows, complementing the product-based perspective in section I, and the country-based perspective in sections II.A and B. It briefly addresses the hypothesis that high skill and technology-intensive products are the most dynamic products in the exports of developing countries because of the increased importance of vertical global production sharing. The section first examines whether the most dynamic products in developing country exports are also among the most dynamic products in developing country imports and then examines bilateral trade flows of selected dynamic products between key regions in world trade. Box 1 provides a brief review of preferential tariff provisions for international production sharing.

The analysis of dynamic products in developing country imports covers a shorter period (i.e. 1988-1998) than the above analysis of exports because of the very low degree of reliability of import data prior to 1988. Table 10 lists the 20 most dynamic products in developing country imports during the period 1988-1998 and for each of these products indicates its position in developing country exports (column 5). The table shows that the product groups in the electronics sectors which experienced dynamic export performance are also among the most dynamic imports, lending support to the hypothesis that rapid export growth in these items is largely due to vertical production sharing. It is also interesting that four out of the 20 most dynamic products in developing country imports are in the textile and clothing sectors (SITC 65 and 84) which is most likely due to the spread of global 
production networks in the apparel commodity chain over the past 20 years. The same argument probably holds for leather (SITC 612) and footwear (SITC 851).

Box 1

\section{Preferential tariff provisions for international production sharing}

Special tariff provision for international production sharing arrangements centres mainly around two major countries or country groups on the import side, namely the United States and the European Union (EU). The United States implemented special tariff provisions already in 1964 to encourage the use of US-origin content in foreign assembly operations. Such products were returned under tariff items 806.30 and 807.00 up to 1988 when this special tariff treatment was continued with some modification under the productionsharing provisions of Chapter 98 of the Harmonized Tariff Schedule of the United States (HTS). These provisions permit a duty exemption for the value of US-made components that are returned to the US as parts of articles assembled abroad (HTS 9802.00.80) and that do not require further processing in the US, or for articles using US-origin metal (except precious metal) that are returned to the United States for further processing (HTS 9802.00.60). In addition, because of NAFTA, HTS 9802.02.90 was created to allow for the duty-free treatment of textile and apparel products assembled in Mexico from US-formed and US-cut fabric (under the latter, value added in Mexico is free of duty in addition to the value of US-cut fabric pieces and US-made fasteners, as under 9902.00.80). ${ }^{14}$

Outward processing trade (OPT) between the European Union and its trading partners ${ }^{15}$ has been concentrated in labour-intensive sectors, particularly textiles and clothing. The legislation on OPT goes back to the second extension of the Multi-Fibre Agreement (MFA) in 1982, when quotas for OPT were included for the first time in MFA III (1982-1986). The special treatment of textiles and clothing imports of the EU consists generally in applying customs relief within certain import limits or surveillance arrangements provided for in the bilateral textile agreements concluded by the EU with a number of supplier countries under the MFA. In practice, this usually means a combination of voluntary export restrictions (VERs), applied by the EU against the supplying country, and tariff suspension. This is a kind of preferential tariff quota on OPT re-imports but applied against suppliers on a selective basis. Access to the quota for OPT operators in the EU is subject to their meeting a number of legal and economic conditions. Countries in Central and Eastern Europe and the Mediterranean region have been the main beneficiaries of the EU's OPT-scheme. The importance of this scheme is reflected by the fact that in Germany more than two thirds of total trade in textile and clothing products with countries in Central and Eastern Europe are part of outward-processing operations (WTO, 1998, p. 94).

However, preferential tariff provision included in regional trade agreements among developing countries such as MERCOSUR and the ASEAN Free Trade Agreement have also had a substantial impact on the dynamism of specific products in the countries which are affected by these agreements. This applies, for example, to the creation or consolidation of a regional automobile industry in Latin America and the ASEAN regions, which has given rise to a substantial increase in foreign direct investment in these countries as well as in horizontal production sharing among them. ${ }^{16}$

The remainder of this section reports the main results of an examination of changes in market shares of bilateral trade between key countries and country groups in world trade. Focussing on the most export-dynamic products and the most rapidly growing products within each group of the product classification used in section I.B. (iii), Mayer (2002) examines data on bilateral trade flows and shows that a rapid increase in two-way trade between developed and developing countries was the main driving force behind the majority of products which have shown dynamic growth in both world and developing country exports over the period 1980-1998. This applies in particular to trade in those

\footnotetext{
14 For a more detailed account, see USITC (1999).

15 This paragraph draws on ECE (1995) and WTO (1998).

16 For a more detailed discussion see Romijn et al (2000).
} 
industrial sectors for which earlier studies (Ernst and Guerrieri (1998), Hummels, Ishii and Yi (1998), Gereffi (1999), Yeats (2001), and $\mathrm{Ng}$ and Yeats (2001)) documented the increasing importance of global production sharing. The products in the sectors concerned include parts and components for electrical and electronic goods (SITC 759, 764, 772 and 776), parts and accessories for motor vehicles (SITC 784) and apparel (SITC 84). The bilateral trade flow data suggest that global production sharing has played an increasingly important role also in trade flows of optical instruments (SITC 871) and medicinal instruments (SITC 872). These two products rank very high in terms of both growth of world exports during 1980-1998 and the indices of dynamism based either on world export values or on shares in total world exports. Moreover, these product groups are a driving force of the rapid growth of high skill- and technology-intensive, as well as science-based, manufactured exports from developing countries.

\section{Summary and conclusions}

The analysis of dynamic products in the exports of country groups and of their importance in the export composition of selected developing countries suggests that there is a strong geographical concentration at both regional and country levels with regard to the origin of these dynamic products. At the country-group level, developed countries and developing countries in Asia (both the first-tier NIEs and other developing countries in East Asia) have been a driving force of product-specific dynamism in world exports. At the country level, dynamic products in world exports represent a relatively high share in the exports of those countries that are geographically close to one of the main developed country markets. The examination of dynamic products in developing countries' imports and of bilateral trade flows in selected dynamic products between key regions in world trade supports the hypothesis that product-specific export dynamism is to a large extent a reflection of the increased importance of global production sharing.

\section{CONCLUSIONS AND POLICY IMPLICATIONS}

The values and market shares of three product categories have grown most rapidly in world non-fuel exports during the period 1980-1998: electrical and electronic goods including parts and components for such goods, goods that require high R\&D expenditures and that are characterized by high technological and managerial complexity, and labour-intensive products (in particular clothing). These are also the products found in earlier studies to have been affected most by two phenomena of the world trading system that have rapidly gained in importance over the past few years, namely the horizontal and vertical fragmentation of production processes at the international level. ${ }^{17}$ Export products which have experienced the most rapid growth and which have a relatively high average share in world totals are also those whose export value growth can be best predicted, suggesting a

\footnotetext{
17 It is clear that factors other than those associated with the growing importance of international production sharing have also played a crucial role in determining differences in export growth across products over the past 20 years. Such factors include product-specific differences in the income elasticity of demand and in the development of market access conditions. However, an analysis of these factors goes beyond the scope of this study.
} 
sustained movement in world exports towards the growing significance of a limited number of products.

At the country group level, developed countries and developing countries in East Asia - most notably the first-tier NIEs - have been a driving force of product-specific dynamism in world exports. At the country level, dynamic products in world exports represent a relatively higher share in the exports of countries that are geographically close to one of the main developed country markets. The examination of dynamic export products in developing countries' imports and of bilateral trade flows in selected dynamic products between key regions in world trade support the hypothesis that productspecific export dynamism is to a large extent a reflection of the increased importance of global production sharing.

With regard to specific product groupings, exports from the high skill- and technologyintensive category have grown most rapidly. Strikingly, the growth rates of exports from developing countries exceed those of world exports by a higher margin the greater is the skill and technology intensity of the product category. However, this does not necessarily imply that there has been a rapid and sustained technological upgrading in the exports of developing countries. This is because rapid growth in developing country exports of skill- and technology-intensive products started from a relatively low base in the early 1980s and, in particular, because the involvement of developing countries is usually limited to the labour-intensive stages in the production process of these goods in the context of international production sharing. This implies that simple measures of growth in gross export values are poor guides for an assessment of the nature of participation of developing countries in world trade.

The findings also suggest that developing country exports tend to be increasingly concentrated in computers and office equipment, communications equipment and semiconductors, and clothing. All of these products involve labour-intensive production processes. Thus, there is a risk that the simultaneous drive in a great number of developing countries, including in particular those with a large economy, to export such dynamic products may cause the benefits of any increased volume of exports to be more than offset by losses due to lower export prices.

Bearing these caveats in mind, getting involved in global production sharing appears to be a key element of any strategy that takes the growth performance of specific products in world exports as a guide. Whereas the findings suggest that countries situated geographically closer to developed countries have an edge over others in integrating into global production sharing, it needs to be recognized that preferential market access regulation has typically given an impetus towards vertical international production sharing and regional integration. Moreover, there are indications to suggest that the integration in international production networks by developing countries in Asia is much broader than that of countries that are geographically close to the United States or the European Union: enterprises in Asian countries operate regional production networks but also export to the United States and Europe, while enterprises in Central Europe tend to concentrate on production sharing with the European Union and enterprises in countries close to the United States, notably 
Mexico, tend to be included in production networks only with the United States. This means that geographic distance to one of the main developed country markets may not be a binding constraint to being included in international production networks.

Becoming part of an international production network can give substantial impetus to a developing country's development and industrialization strategy mainly because it broadens the range of sectors on which developing countries can base their quest for industrialization. Given that productspecific characteristics allow partitioning into various stages the production process of an increasing number of industrial sectors, it is no longer necessary for producers to master entire production chains and to organize them within single firms. Rather, they can focus on mastering just one facet of production and on no more than a limited subset of all the activities involved in making a final product. This is likely to entail large savings in learning costs and can allow small- and medium-sized domestic companies to compete successfully with multinationals. Given relative factor endowments, developing countries may begin by acquiring competence for the more labour-intensive components of complex products and gradually move on to more skill- and technology-intensive activities.

On the other hand, it seems likely that with geographically dispersed production sites, the spillovers from subcontracting or hosting affiliates of multi-national enterprises (MNEs) are reduced because the package of technology and skills required at any one site is narrower and because crossborder backward and forward linkages are strengthened at the expense of domestic ones. When only a small part of the production chain is involved, outcontractors and MNEs have a wider choice of potential sites since these activities take on a more footloose character, thereby strengthening their bargaining position vis-à-vis the host country. This is likely to create a tendency towards increased competition among developing countries, offering more and more substantial concessions on taxation and trade issues to developed-country firms in order to compensate shifting comparative advantage within the group of developing countries or cost-cutting and downsizing pressures of the developedcountry firms.

The growing importance of international production networks raises the degree of production complementarities between developed and developing countries. This implies that a greater share of developing-country production and exports come to depend on the decisions and performance of foreign firms and countries. This reduces policy autonomy in developing countries regarding their formulation of a development strategy that emphasizes national capabilities and goals. Moreover, developing countries have usually not been involved in the skill and technology-intensive parts of the production process which carries the risk of developing countries' getting locked in to their current structure of comparative advantage, with its emphasis on labour-intensive activities, while the exploitation of potential comparative advantage in the higher-tech stages of production is delayed. This risk is particularly high where trade flows are based on preferential market access that requires production inputs to be sourced from the developed-country partners. Where this is the case, the geographic dispersals of production activities are likely to lead to less, rather than more technology transfer. 
The present study also indicates areas where further research is needed. It would be desirable to disentangle volume and price effects in measuring product-specific export dynamism by concentrating, for example, on a few dynamic export products and a small number of dynamic import markets for which the required data are available. It would also be desirable to examine more closely the impact of product-specific export dynamism on productivity and growth overall and in the respective industrial sectors. It would be interesting to see, for example, whether a given increase in export value has been associated with differences in the rate of income growth in exporting countries depending on the kind of products which generated the increase in export value. Doing so would give some indication also on whether product groups for which differences in long-run sectoral productivity growth have been observed in large developed countries show similar differences also in developing countries. 


\section{APPENDICES}

\section{Appendix I: Availability and limitations of data}

For this study, a data set was created from the repository Economic Time Series database (ETS) that has been maintained by the UNCTAD secretariat. The relevant time series are updated annually by processing a file received from the United Nations Statistics Division (UNSD) in New York. UNSD prepares this file for the publication of Volume II of the International Trade Statistics Yearbook (Commodity Tables, Group (3-digit) level of the SITC, Revision 2). The file includes data from COMTRADE as well as UNSD-estimates. The data series in ETS are further refined on a continuous basis by including the most recent official updates of COMTRADE.

The data used in the study covers the period from 1980 to 1998 for exports and the period from 1988 to 1998 for imports. The data are fully consistent for the period 1988-1998. For the period 1980-1987, export data can be considered to be reasonably accurate, except for products with a very small share in world exports for which incomplete reporting can have a significant impact on the calculations. Data prior to 1980 are considered to be much less reliable. The data are in current US dollar and have two interesting features. First, the data are exhaustive, i.e., there are no missing values within any countryyear subset. Second, each subset is based on either official sources or estimates.

The data set includes all products classified in the Standard International Trade Classification (SITC) Revision 2, except SITC 931 (special transactions and commodities not classified according to kind) which is a residual category, and SITC 286 (ores and concentrates of uranium and thorium), SITC 333 (crude petroleum), SITC 351 (electric current), SITC 675 (Hoops and strip or iron and steel), SITC 688 (uranium depleted in U235 and thorium, and their alloys), SITC 911 (postal packages not classified according to kind), SITC 961 (coin other than gold coin), not being legal tender, and SITC 971 (gold, non-monetary) which are excluded because data for these categories "were poorly reported and contain many estimates which are not sufficiently explainable" (United Nations (1999, p.1)). The remaining products in SITC section 3, namely SITC 322 (coal), SITC 323 (coke and briquettes), SITC 334 (refined petroleum products), SITC 335 (residual petroleum products) and SITC 341 (gas) are also excluded, so that the analysis in based on non-fuel merchandise trade, i.e. a category that is frequently used in trade analysis.

One element in the evolution of the world trading system over the past twenty years that can have a significant impact on the calculations of this study is the integration of previously isolated economies into the world trading system. For some of these countries, external trade was not recorded in international statistics because, for example, for certain years the data were not available on an internationally comparable basis. This is the case particularly for the member countries of the former Council For Mutual Economic Assistance (CMEA) and China. Whereas the former continue to have a relatively low share in current world trade, China has become one of the top ten world traders. Given that the time series on Chinese exports start only in the mid-1980s, calculations on export dynamism will be biased for those products which had been exported by China but have only been registered since the mid-1980s. This poses the question as to how to deal with this problem. Excluding China from the study would seriously distort actual trade patterns, while starting the analysis only at the end of the 1980s would eliminate important information on the long-term development of world exports. Given the fact that China entered global markets as an exporter of significance only in the mid-1980s, there is a high probability that the beginning of the data series in the mid-1980s actually marks China's entry into the world trading system in an accurate manner with respect to most of its manufactured exports, i.e. the products for which the value of China's exports has grown most, and that therefore only the calculations concerning a few primary products are affected by the data problem in a considerable way, the best possible solution appears to be not to make any, necessarily arbitrary, corrections to the data. In interpreting the statistical results, however, it will be important to bear this issue in mind. 


\section{Appendix II: Description of statistical and econometric methods}

Degree of market concentration: The Herfindahl-Hirschman Index (HHI) is a measure of the degree of market concentration. For the purposes of this study, the HHI can be calculated for each product by taking the sum of the squared values of the market shares of all countries that export a particular product, i.e. $H H I_{j}=\sum\left(S_{i j}\right)^{2}$ where $S_{i}$ is the share of country $i$ expressed as a percentage of total world exports of products $j$. This means that the HHI ranges between 43, indicating that all 234 countries in the sample have equal shares (i.e. 0.43 per cent) in a product's total exports, and 10,000, indicating that the product is exported by only one country.

\section{Composite measures of dynamism}

As a measure of dynamism, the time-dependent path of growth represents a one sided characteristic of what constitutes a dynamic product. Issues like volatility, predictability, growth in shares, and growth in the last period are not usually considered when dynamism is measured. Moreover, time dependence may not in itself explain why a product should be dynamic. A product's path of growth may be complex and its relationship with time may not necessarily be linear. Therefore, the question to which an answer shall be provided is: can a comprehensive measure of what constitutes a dynamic product be developed and, if so, what elements should be included in assessing the performance of an export product over time. In attempting to answer this question, the following arguments were deemed relevant to the analysis of dynamic behaviour over time:

- Time-path dependence assigns equal weights to every period in time. The distant past may not affect the future as the very recent past. In fact, recent developments in theory indicate that composite measures that assign higher weights to growth in the last periods tend to capture more of the true behaviour of a product over time. Evidently, price dependent export series exhibit a relatively highvolatility and, therefore, an emphasis on growth in the last period does introduce a needed momentum into the analysis of dynamism;

- Growth in shares represents another missing component in trend growth over time. Incorporating the consistency of share growth over time into the analysis of dynamism offsets the impact of absolute variations on an export series. A product whose share experienced consistent growth on a trend represents a highly dynamic product;

- A high growth rate over time can conceal within it elements of volatility and unpredictability that negatively contribute to dynamism. Generally speaking, a predictable high-growth/low-volatility product represents the surest product on the export market. Introducing the negative impacts of low predictability/high volatility into composite measures of dynamism is relevant for the definition of a dynamic product.

Given the numerous possibilities by which a composite index of dynamism can be formed on the basis of the above categories, the following three indices of dynamism may be sufficient for a relatively comprehensive definition:

- A comprehensive index $\left(I_{c}\right)$ that includes long-term growth (1980-1998), short-term growth (1996-1998), volatility around the trend of long-term growth, and growth in the share of a specific product in total world exports (1980-1998), i.e.

$$
I_{c}=\alpha_{1} * \text { long-term growth }+\alpha_{2} * \text { short-term growth }+\alpha_{3} * \text { volatility }+\alpha_{4} * \text { growth in share }
$$


Volatility: dispersion around the trend is generally meant to represent the extent of volatility in time series. Thus, where the coefficient of determination measures the closeness of fit or the ratio of explained to total variations in an export series, its opposite, the poorness of fit or the ratio of unexplained to total variations should capture the extent of volatility around a trend, i.e.

Volatility $=1-R^{2}$, where $\mathrm{R}$-square is the coefficient of determination.

The drawback to such an approach lies in the specification that an export series has a linear relationship with time. However, it is not possible to study and implement the different specifications of the many export series with time and still arrive at a unique general benchmark that may serve the purpose of comparison. For comparative reasons, the fact that the same measure can be applied as a rule to all the export series seemed to be a reasonable starting point.

- A share-based index $\left(I_{s}\right)$ that accounts for the linear trend in the share of a specific product in total world exports (1980-1998), the volatility around the trend in the share (1980-1998), and the rate of growth in the share over the period 1996-1998, i.e.

$$
I_{c}=\alpha_{1} * \text { trend share }+\alpha_{2} * \text { short-term growth in share }+\alpha_{3} * \text { volatility }
$$

- A predictability/volatility index $\left(I_{p v}\right)$ that encompasses predictability of long-term growth, volatility of long-term growth, and long-term growth (1980-1998), i.e.

$$
I_{p v}=\alpha_{1} * \text { predictability }+\alpha_{2} * \text { volatility }+\alpha_{3} * \text { long-term growth }
$$

Predictability: a simple and widely used estimation procedure known as AR1 was used for assessing the predictability of SITC 3digit level export series. The principal meaning behind this approach is that present behaviour can be predicted on the basis of past performance, i.e.

$y_{t}=E_{t}\left(y_{t} \mid y_{t-1}\right)$

Hence the following regression was fitted: $y_{t}=\beta_{0}+\beta_{1} y_{t-1}+\varepsilon_{t}$

where the autoregressive order is one and the differencing order is also one.

The coefficient of determination arising from the regression determines the level of fit and, hence, predictability. Where the autoregressive order was higher than one, i.e. when prediction can be made on the basis of the behaviour of many past periods, the regression was restricted to a first order autoregression because this allowed comparability across all the export series with a single benchmark, i.e. the coefficient of determination arising from a single lag in the series.

The weights assigned for each variable in the index are generated from the data through the method of factor analysis. The use of this method allows the values assigned to each weight $(\alpha)$ to be derived on the basis of correlations between the variables included in the index. ${ }^{18}$

\footnotetext{
18 Factor analysis attempts to identify underlying variables, or factors, that explain the pattern of correlations within a set of observed variables. Factor analysis is often used in data reduction to identify a small number of factors that explain most of the variance observed in a much larger number of manifest variables. For further details of this method see D. Child, The Essentials of Factor analysis, 1970.
} 


\section{$\underline{\text { Analysis of variance }}$}

Analysis of variance, or ANOVA, is a method of testing the null hypothesis that several group means are equal in the population, by comparing the sample variance estimated from the group means to that estimated within the groups. In the context of this study, the effect of the technological profile on the growth in the share of the product group is tested. This is a standard procedure which attempts an answer to the question of whether the technological profile of a product contributes to the growth of its share in world exports.

The null hypothesis being tested that the classification according to production profile of different product groups are equal vis-à-vis the alternative hypothesis that the means of the growth in the shares are unequal.

The applied $\mathrm{F}$ test is $\mathrm{F}^{*}=\sum\left(\mathrm{y}^{2} /(\mathrm{K}-1)\right) / \sum\left(\mathrm{e}^{2} /(\mathrm{n}-\mathrm{K})\right)$.

All $\mathrm{F}$ and $\mathrm{t}$ tests confirmed a significant difference in the means of the groupings on the basis of either the classification given in Appendix 1 3.I or that given in Appendix 1 3.II. The orderings for such groupings was given in the text under the appropriate heading. 


\section{Appendix III: Definition of product categories}

\section{Product categories by factor intensity ${ }^{19}$}

$\underline{\text { SITC Rev. } 2 \text { Codes }}$

$\underline{\text { Non-fuel primary commodities }}$

0, 1, 2 (less, 233, 244, 266, 267), 4, 68

Labour-intensive and resource-intensive manufactures

Leather, textiles, apparel, and footwear

$61,65,83,84,85$

Toys and sports equipment

894

Wood and paper products

$63,64,82$

Non-metallic mineral products

66

$\underline{\text { Low skill-, technology-, capital- and scale-intensive manufactures }}$

Iron and steel

Fabricated metal products

69

Simple transport equipment

78 (less 781-784) + 79 (less 792-793)

Sanitary and plumbing equipment

81

Ships and boats

793

$\underline{\text { Medium skill-, technology-, capital- and scale-intensive manufactures }}$

Rubber and plastic products

62,893

Non-electrical machinery

$71-74$

Electrical machinery other than semiconductors

77 (less 776)

Road motor vehicles

781-784

$\underline{\text { High skill-, technology-, capital- and scale-intensive manufactures }}$

Chemical and pharmaceutical products

Computers and office equipment

Communications equipment and semiconductors

Aircraft

Scientific instruments, watches and photographic equipment
5

75

76,776

792

87,88

19 This classification is based on UNCTAD, 1996, Trade and Development Report 1996, (United Nations: New York and Geneva) 
2. Product categories by main factor affecting the competitive process ${ }^{20}$

$\underline{\text { SITC Rev. } 2 \text { Codes }}$

$\underline{\text { Non-fuel primary commodities }}$

$\underline{\text { Resource-intensive manufactures }}$

Woods products

Non-metallic mineral products

$\underline{\text { Labour intensive manufactures }}$

Leather, textiles, apparel, footwear

Fabricated metal products

Other manufactures, excluding plastics

$\underline{\text { Differentiated products requiring specialized suppliers }}$

Non-electrical machinery

Electrical machinery

Communications equipment

$\underline{\text { Scale-intensive manufactures }}$

Paper

Chemicals excluding pharmaceuticals

Rubber and plastic products

Iron and steel

Road motor vehicles

Ships and other transport equipment other than aerospace
63,82

66

$61,65,83,84,85$

69

89 less 893

$71,72,73,74$

77

76

64

5 less 54

62,893

67

781-784

79 less 792

$\underline{\text { Science-based manufactures }}$

Aircraft

Computers and office equipment

Pharmaceuticals

Scientific instruments
792

75

54

87,88

20 This classification is based on OECD, 1994, Industrial Policies in OECD Countries, Annual Review 1994, (OECD: Paris). 
3. Agricultural goods which are high-value products and/or items with an income elasticity of demand greater than one ${ }^{21}$

$\underline{\text { SITC Rev. } 2 \text { Codes }}$

Meat and meat products

$011,012,014$

Dairy products

$022,023,024$

Fish, fish products and sea food

034, 035, 036, 037

Vegetables

054,056

Fruit, nuts and fruit preparations

057,058

Spices

075

Fixed vegetable oils and fats

423,424

4. By long-run growth of total factor productivity in large developed countries ${ }^{22}$

$\underline{\text { Non-manufacturing sectors }}$

\section{$\underline{\text { ISIC Code }}$}

$\underline{\text { Low TFP-growth manufacturing sectors }}$

Food, beverages, and tobacco 31

Paper, paper products, printing and publishing $\quad 34$

Other manufacturing industries $\quad 39$

$\underline{\text { Medium TFP-growth manufacturing sectors }}$

Wood and wood products 33

Non-metallic mineral products, except fuel 36

Basic metal industries $\quad 37$

$\underline{\text { High TFP-growth manufacturing sectors }}$

Textiles, clothing and leather $\quad 32$

Chemicals and chemical products 35

Fabricated metal products, machinery and equipment $\quad 38$

21 This classification is based on Jaffee and Gordon (1993) and World Bank (1994, p. 39).

22 This classification is based on Choudhri and Hakura (2000, p.15). 


\section{FIGURES AND TABLES}

\section{Figure}

1a Growth of world non-fuel exports of different product categories by factor intensity

1b Structure of world non-fuel exports by product category according to factor intensity, 1980-1998

1c Growth of developing country non-fuel exports of different product categories, by factor intensity

1d Structure of developing country non-fuel exports by product category according to factor intensity, 1980-1998

2a Export dynamism of internationally traded non-fuel products, by factor intensity

$2 \mathrm{~b}$ Export dynamism of internationally traded non-fuel products, by main factor affecting the competitive process

3a Growth of world non-fuel exports of different product categories, by main factor affecting the competitive process

3b Structure of world non-fuel exports by product category according to main factor affecting the competitive process, 1980-1998

3c Growth of developing country non-fuel exports of different product categories, by main factor affecting the competitive process

3d Structure of developing country non-fuel exports by product category according to main factor influencing the competitive process, 1980-1998

4a Dynamism of developing country non-fuel exports, by factor intensity

$4 \mathrm{~b}$ Dynamism of developing country non-fuel exports, by main factor affecting the competitive process

\section{Table}

1a The 20 most dynamic products in world non-fuel exports, ranked by average annual export value growth, 1980-1998

1b The 20 most dynamic products in world non-fuel exports, ranked by average annual export value growth, 1996-1998

2 Shares of main exporters, developed and developing countries in world non-fuel exports of the 20 most dynamic products (ranked by index of dynamism based on export values, 1980-1998), 1998

3 The 20 most dynamic products in world non-fuel exports, ranked by index of dynamism based on shares in total exports, 1980-1998

4 Predictability of annual export value growth, selected products, 1980-1998

5 The 20 most dynamic products in world non-fuel exports ranked by composite index on predictability, volatility and growth, 1980-1998

6 Market-share concentration of dynamic products in world non-fuel exports identified on basis of index of dynamism, based on export values, 1980-1998

7 Shares of main exporters, developed and developing countries in world exports of the most dynamic agricultural commodities (ranked by index of dynamism based on export values, 1980-1998), 1998

8 Leading dynamic products by exporting region, ranked by average annual export value growth, 1980-1988

9 Composition of non-fuel exports, selected developing countries, 1996-1998 averages

10 Dynamic products in non-fuel imports of developing countries, by average annual import value growth, 1988-1998 
Figure 1a

Growth of world non-fuel exports of different product categories, by factor intensity

(Index numbers, $1980=100$ )

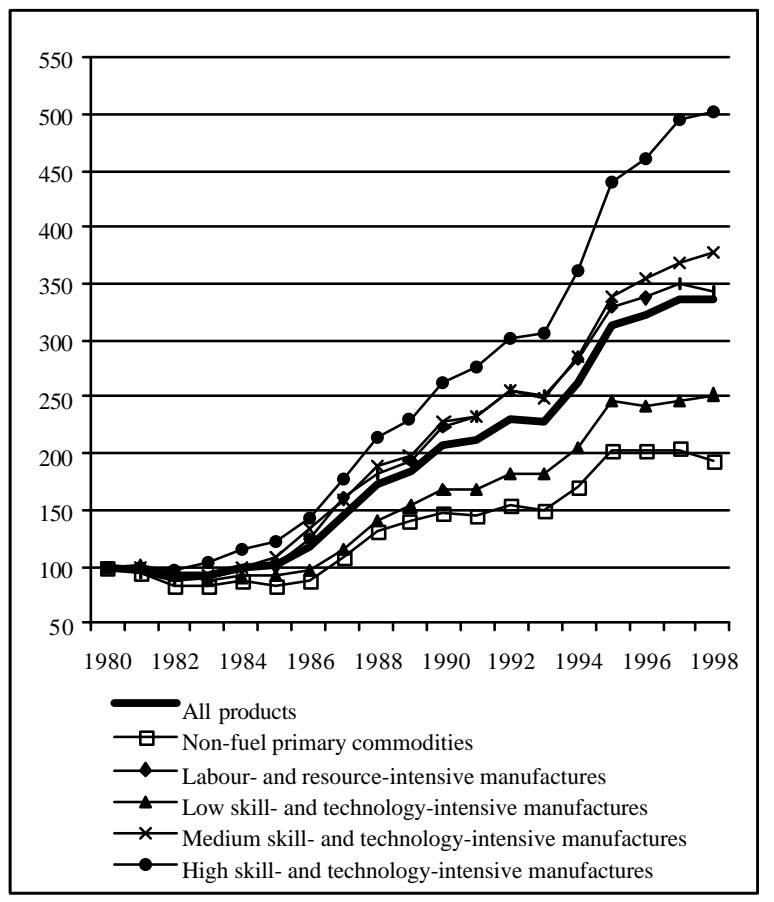

Figure $1 b$

Structure of world non-fuel exports by product category according to factor intensity, 1980-1998 (Percentage share)

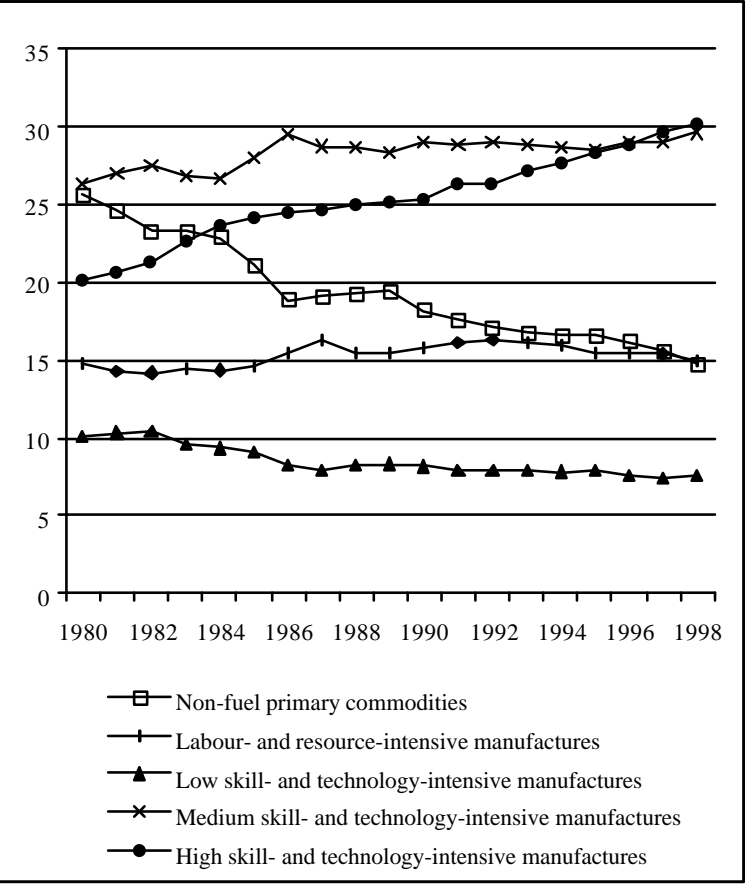

Figure 1c

Growth of developing country non-fuel exports of different product categories, by factor intensity (Index numbers, $1980=100$ )

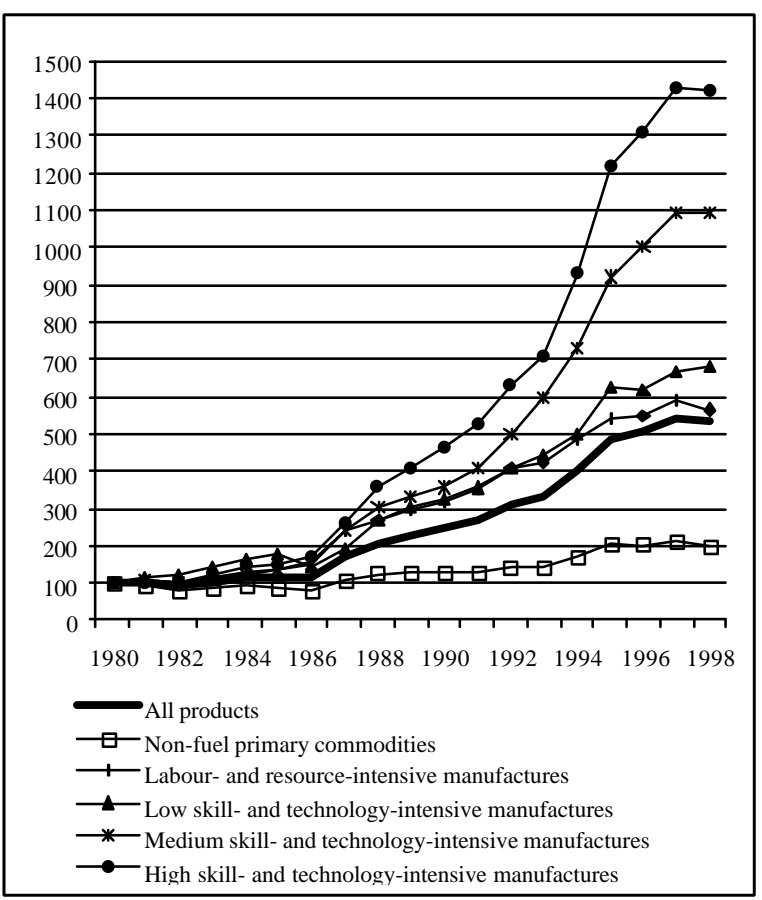

Figure 1d

Structure of developing country non-fuel exports by product category according to factor intensity, 1980-1998 (Percentage share)

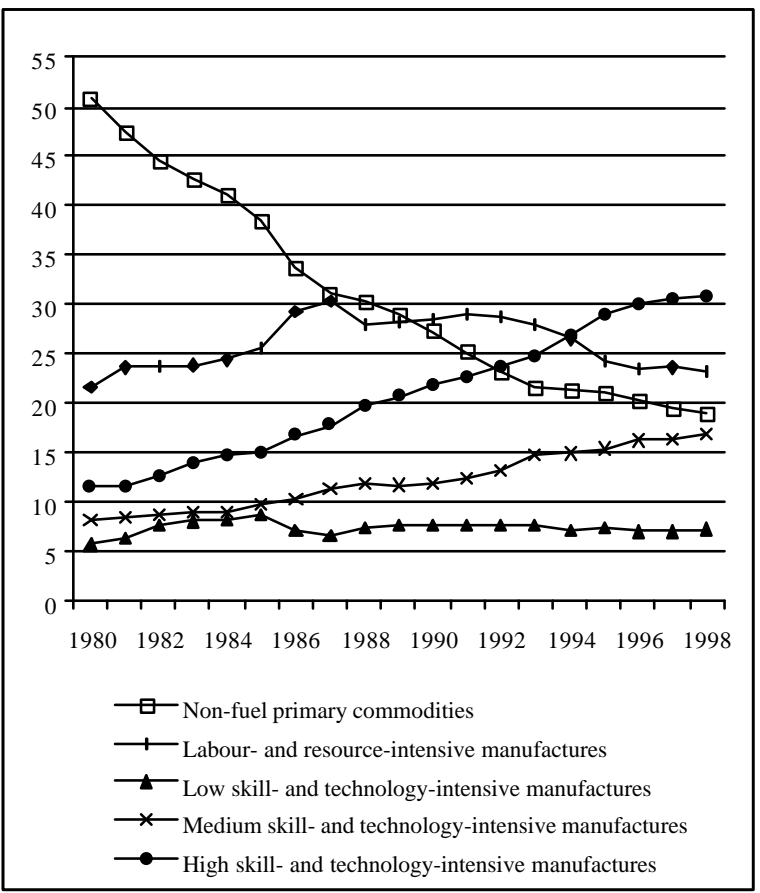

Source: See table 1a.

Note: For the product classification see Appendix III.(i). 
Figure 2a

Export dynamism of internationally traded non-fuel products, by factor intensity

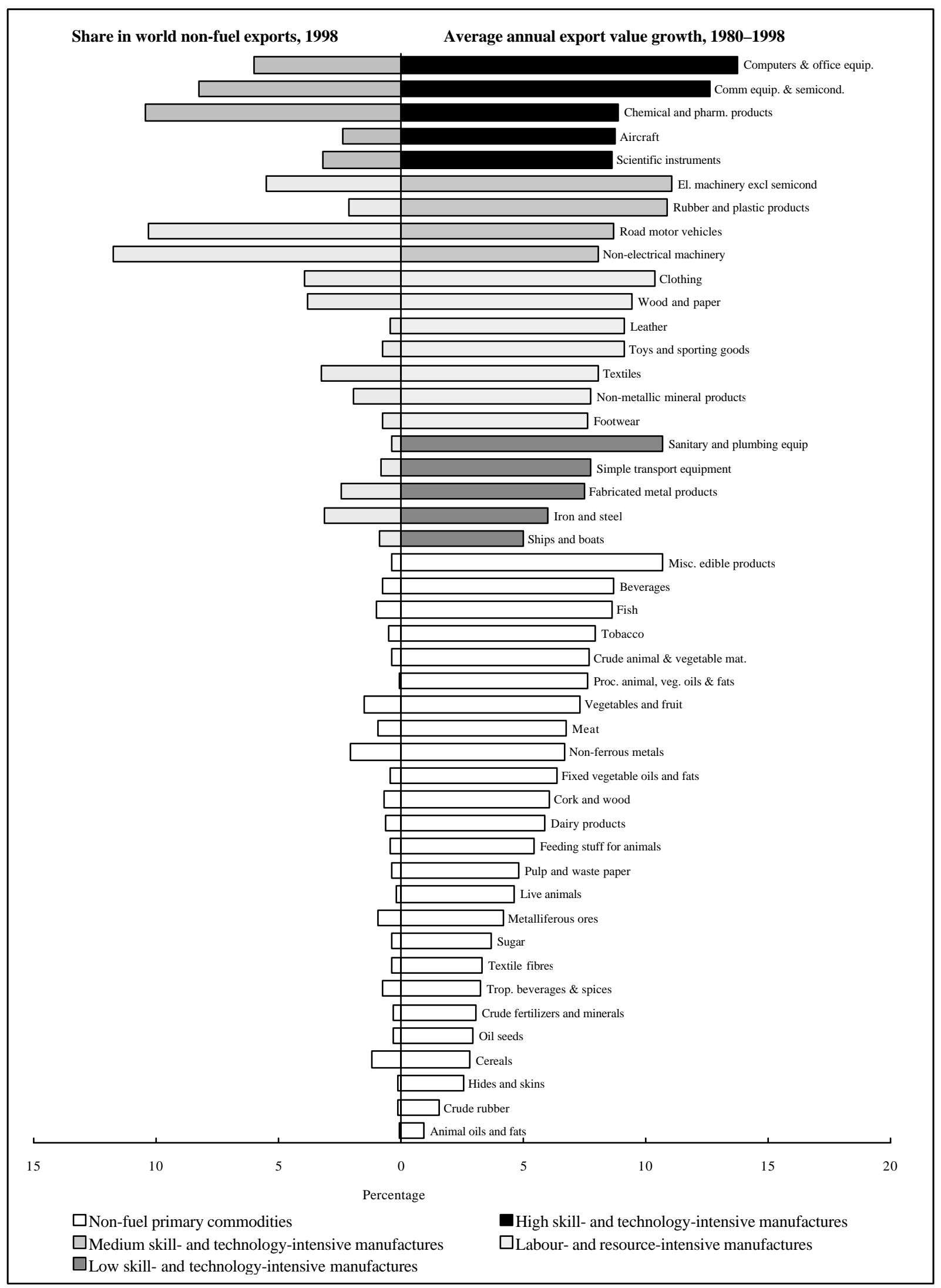

Source: See table 1a.

Note: For the product classification see Appendix III.(i). Both product groups and sub-groups are ranked in decreasing order by their average rate of growth during the period 1980-1998. 
Figure $2 b$

Export dynamism of internationally traded non-fuel products, by main factor affecting the competitive process

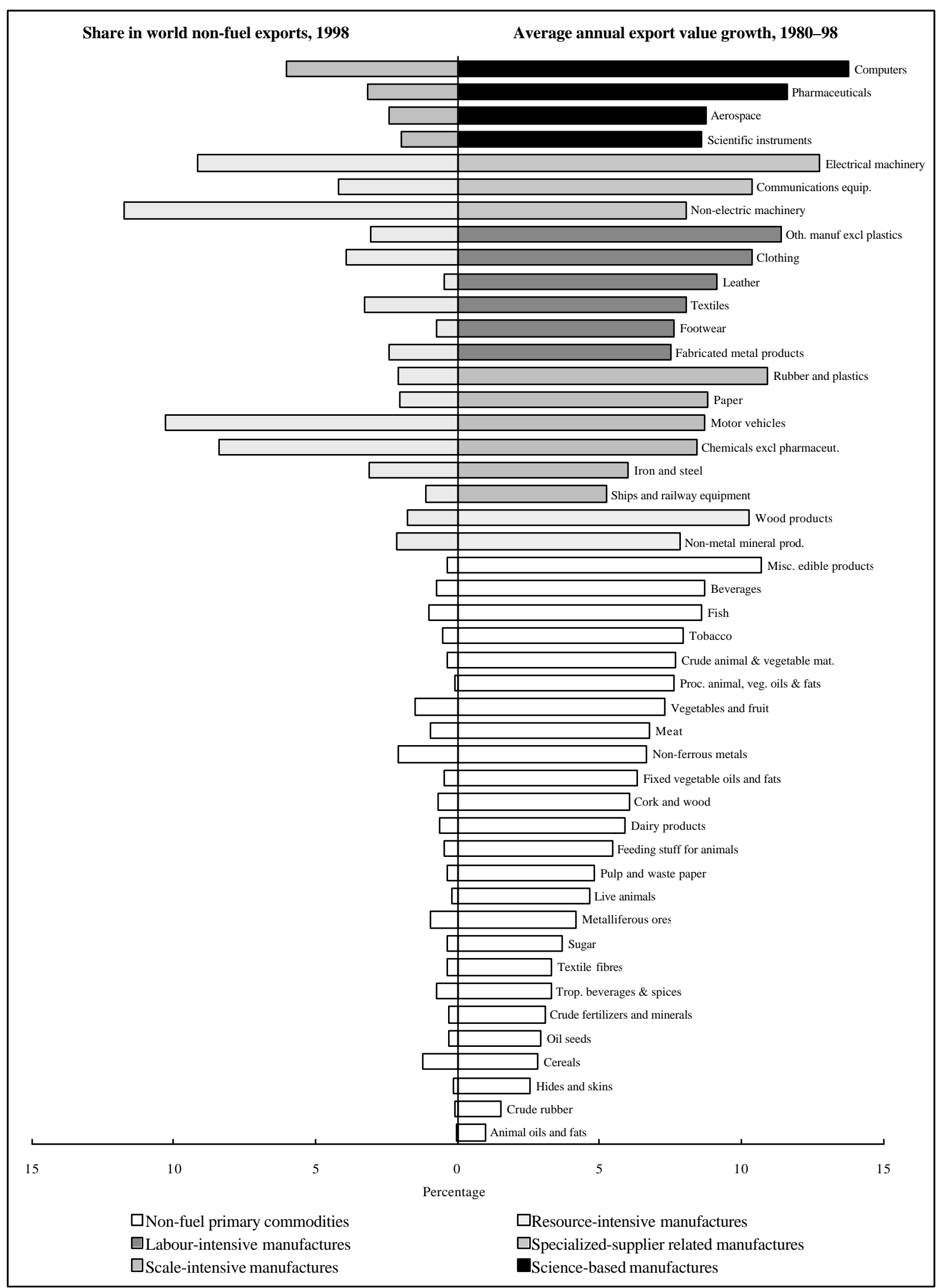

Source: See table 1a.

Note: For the product classification see Appendix III.(ii). Both product groups and sub-groups are ranked in decreasing order by their average rate of growth during the period 1980-1998. 
Figure 3a

Growth of world non-fuel exports of different product categories, by main factor affecting the competitive process $($ Index numbers, $1980=100)$

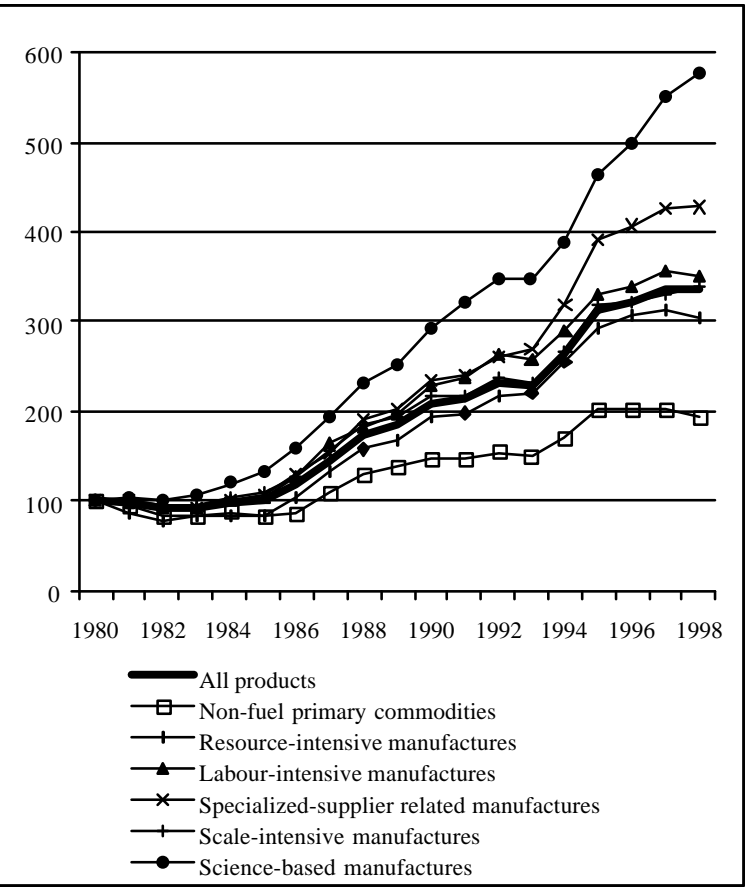

Figure 3b

Structure of world non-fuel exports by product category according to main factor influencing the competitive process, 1980-1998

(Percentage share)

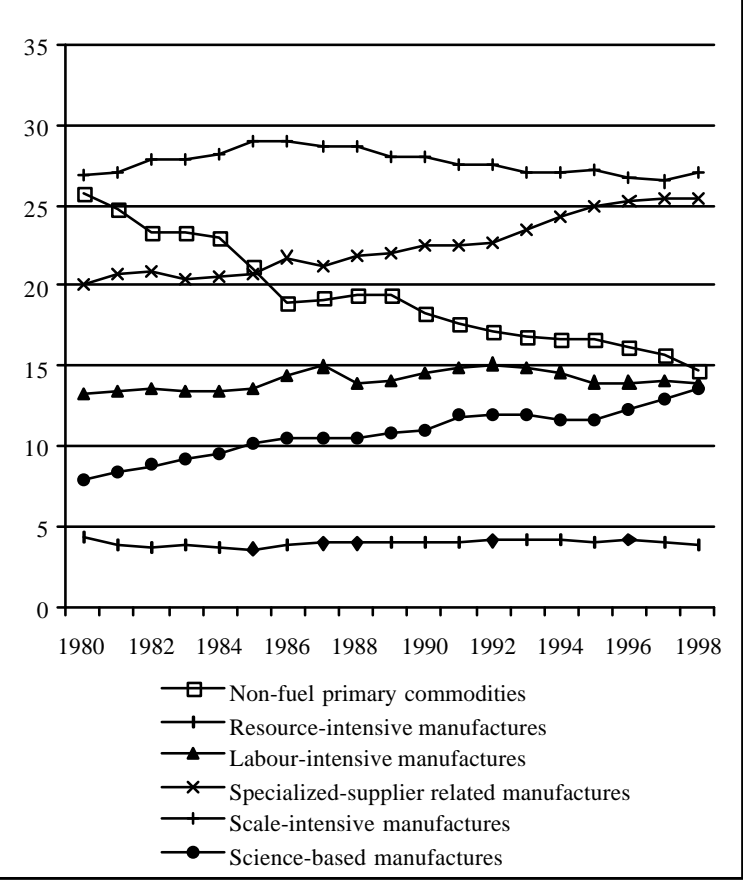

Source: See table 1a.

Note: For the product classification see Appendix III.(ii).
Figure 3c

Growth of developing country non-fuel exports of different product categories, by main factor affecting the competitive process (Index numbers, $1980=100)$

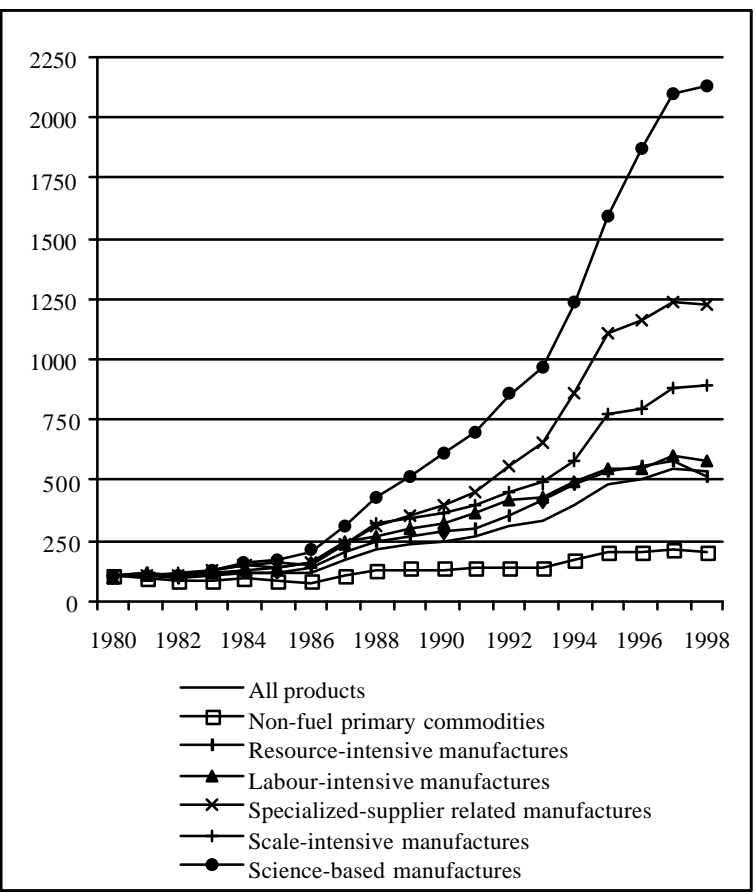

Figure 3d

Str ucture of developing country non-fuel exports by product category according to main factor influencing the competitive process, 1980-1998 (Percentage share)

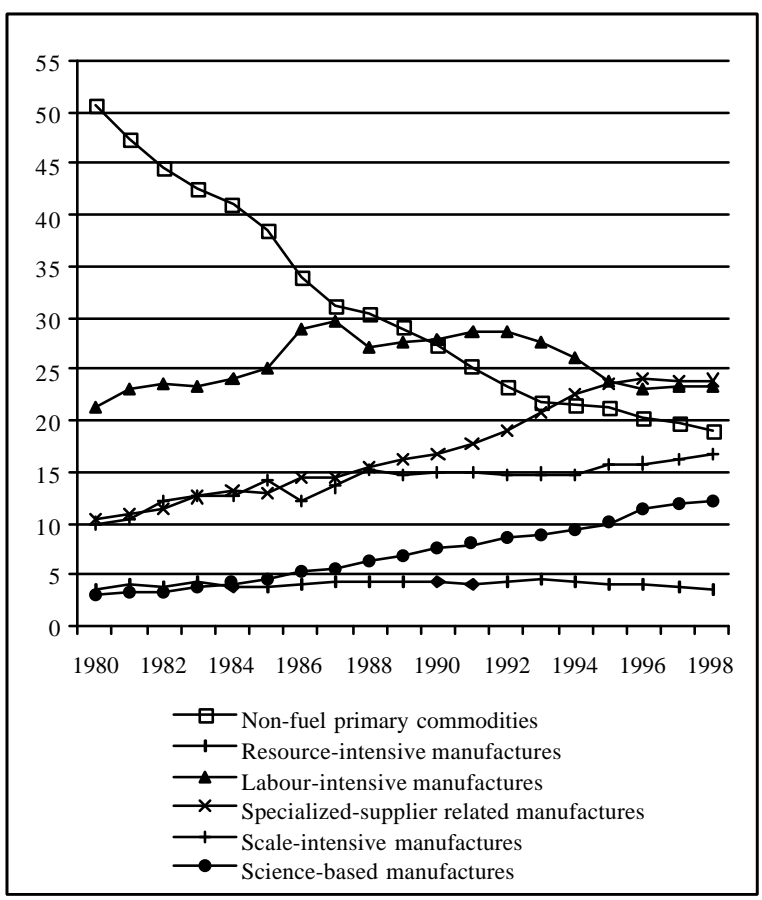


Figure $4 a$

Dynamism of developing country non-fuel exports, by factor intensity

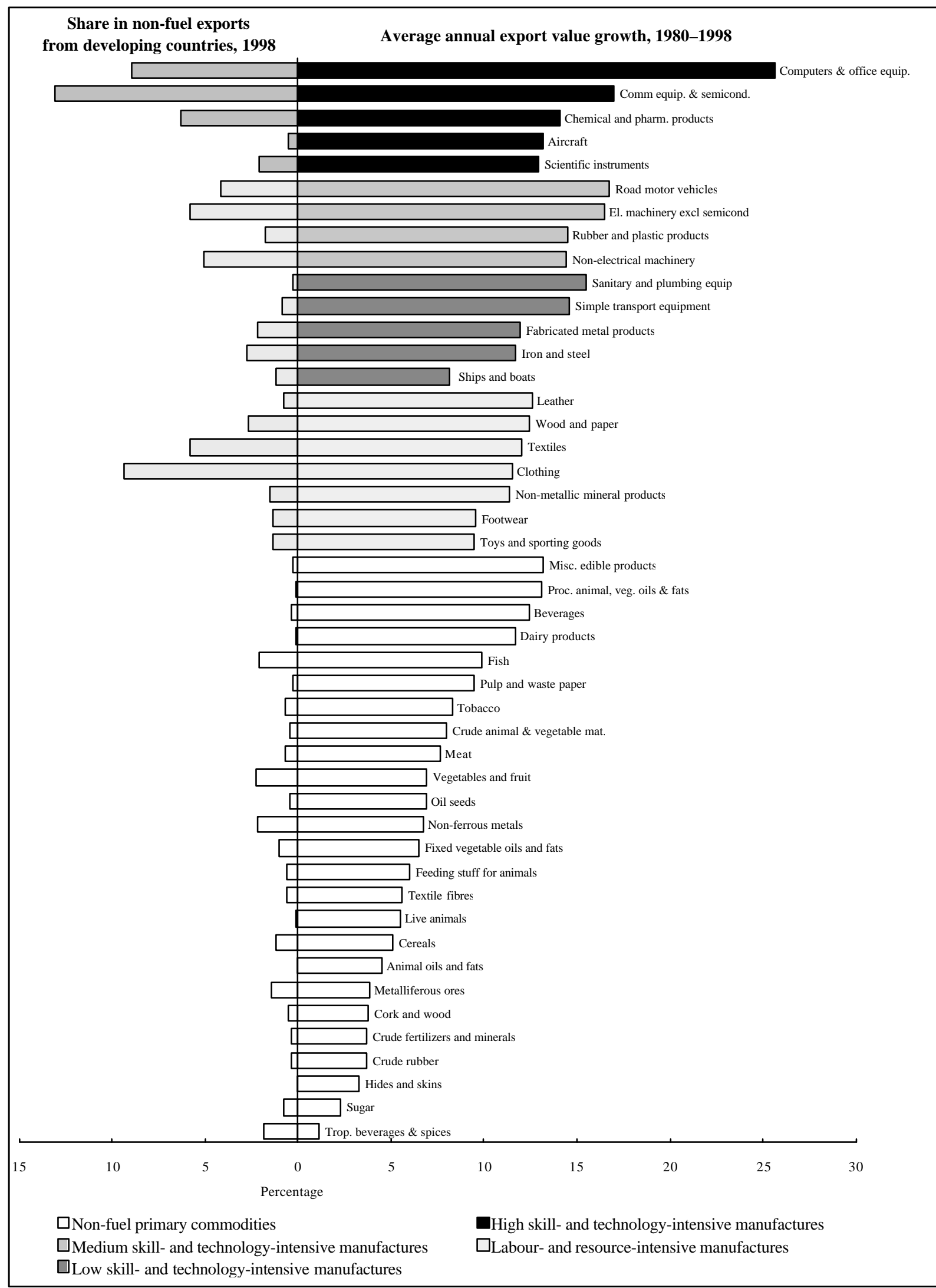

Source: See table 1a.

Note: For the product classification see Appendix III.(i). Both product groups and sub-groups are ranked in decreasing order by their average rate of growth during the period 1980-1998. 
Figure 4b

Dynamism of developing country non-fuel exports, by main factor affecting the competitive process

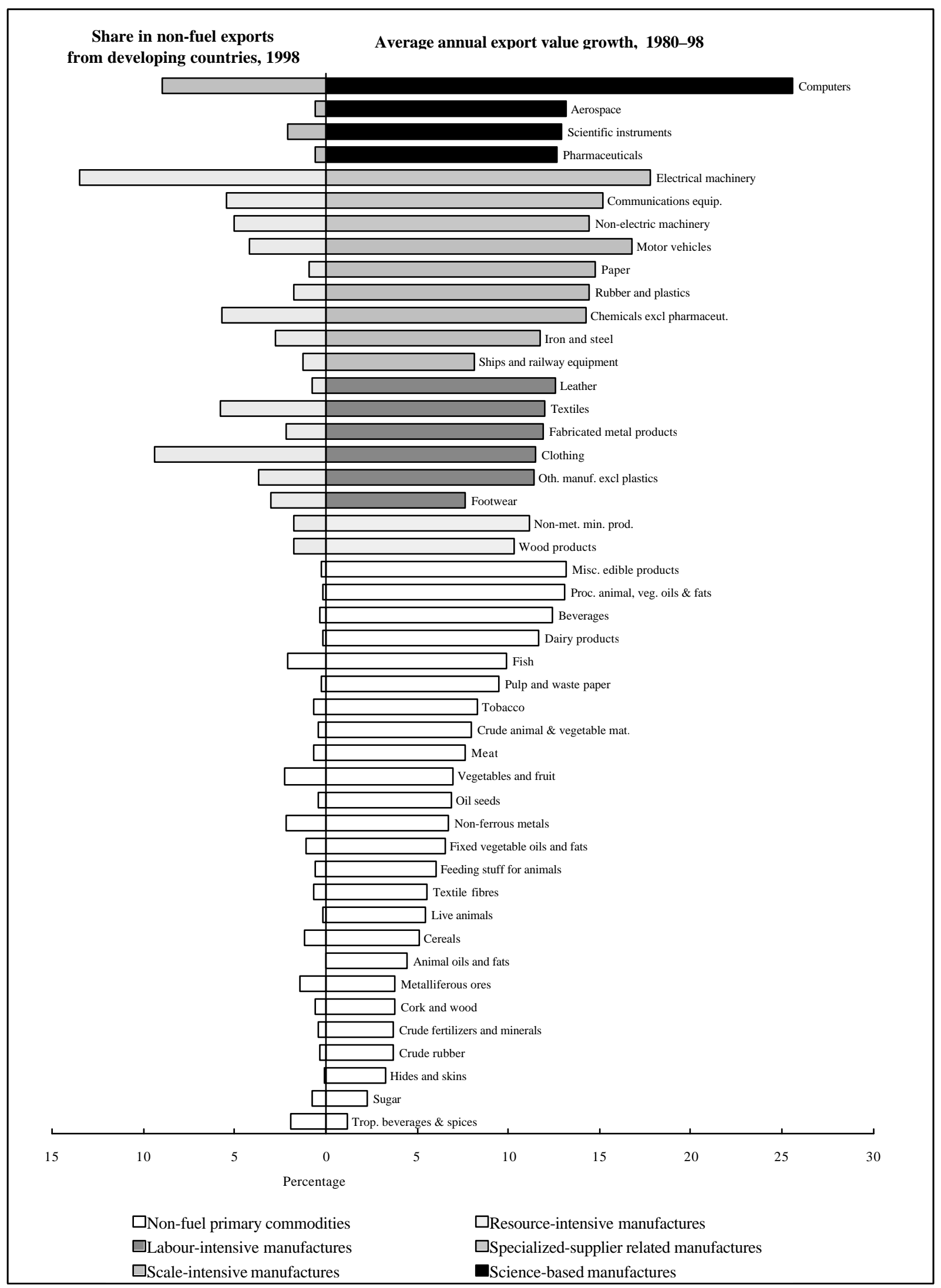

Source: See table 1a.

Note: For the product classification see Appendix III.(ii). Both product categories and individual groups within product categories are ranked in decreasing order by average rate of growth during 1980-1998. 
Table 1a

The 20 most dynamic products in world non-fuel exports, ranked by average annual export value growth, 1980-1998

\begin{tabular}{|c|c|c|c|c|c|c|c|c|}
\hline \multirow[b]{2}{*}{$\begin{array}{l}\text { SITC } \\
\text { code }\end{array}$} & \multirow[b]{2}{*}{ Product group } & \multicolumn{4}{|c|}{$1980-98$} & \multicolumn{3}{|c|}{$1996-98$} \\
\hline & & $\begin{array}{c}\text { Rank } \\
(1)\end{array}$ & $\begin{array}{c}\text { Average } \\
\text { annual export } \\
\text { value growth } \\
\text { (Per cent) } \\
\text { (2) }\end{array}$ & $\begin{array}{l}\text { Average share } \\
\text { in world non- } \\
\text { fuel exports } \\
\text { (Per cent) } \\
\text { (3) }\end{array}$ & $\begin{array}{c}\text { Stability } \\
\text { indicator } \\
(4)\end{array}$ & $\begin{array}{c}\text { Rank } \\
(5)\end{array}$ & $\begin{array}{c}\text { Average } \\
\text { annual export } \\
\text { value growth } \\
\text { (Per cent) } \\
\text { (6) }\end{array}$ & $\begin{array}{c}\text { Average } \\
\text { annual growth of } \\
\text { share in world } \\
\text { non-fuel exports } \\
\text { (Per cent) } \\
\text { (7) }\end{array}$ \\
\hline 776 & Transistors and semiconductors & 1 & 16.3 & 2.2 & 0.98 & 72 & 0.9 & 2.8 \\
\hline 752 & Computers & 2 & 15.0 & 2.1 & 0.98 & 38 & 5.3 & 6.9 \\
\hline 759 & Parts of computers and office machines & 3 & 14.6 & 1.5 & 0.98 & 32 & 6.7 & 8.1 \\
\hline 871 & Optical instruments & 4 & 14.1 & 0.1 & 0.99 & 4 & 37.6 & 28.8 \\
\hline 553 & Perfumery and cosmetics & 5 & 13.3 & 0.3 & 0.97 & 58 & 2.5 & 4.4 \\
\hline 261 & Silk & 6 & 13.2 & 0.0 & 0.59 & 204 & -18.3 & -20.0 \\
\hline 846 & Knitted undergarments & 7 & 13.1 & 0.4 & 0.96 & 16 & 11.2 & 11.8 \\
\hline 893 & Plastic articles & 8 & 13.1 & 0.8 & 0.96 & 51 & 3.3 & 5.1 \\
\hline 771 & Electric power machinery & 9 & 12.9 & 0.3 & 0.98 & 46 & 4.2 & 5.9 \\
\hline 898 & Musical instruments and records & 10 & 12.6 & 0.5 & 0.97 & 127 & -6.1 & -4.5 \\
\hline 612 & Leather manufactures & 11 & 12.4 & 0.1 & 0.94 & 100 & -2.6 & -0.7 \\
\hline 111 & Non-alcoholic beverages & 12 & 12.2 & 0.1 & 0.92 & 124 & -5.8 & -4.1 \\
\hline 872 & Medical instruments and appliances & 13 & 12.1 & 0.3 & 0.98 & 30 & 6.9 & 8.3 \\
\hline 773 & Electricity distributing equipment & 14 & 12.0 & 0.4 & 0.96 & 67 & 1.7 & 3.6 \\
\hline 764 & Telecom equipment, and parts & 15 & 11.9 & 1.9 & 0.98 & 13 & 12.0 & 12.4 \\
\hline 844 & Non-knitted undergarments & 16 & 11.9 & 0.2 & 0.96 & 48 & 3.9 & 5.7 \\
\hline 048 & Cereal preparations & 17 & 11.9 & 0.3 & 0.95 & 116 & -4.7 & -2.9 \\
\hline 655 & Knitted fabrics & 18 & 11.7 & 0.2 & 0.93 & 45 & 4.3 & 6.0 \\
\hline 541 & Medicinal and pharmaceutical products & 19 & 11.6 & 1.2 & 0.98 & 7 & 15.8 & 15.3 \\
\hline 778 & Electrical machinery and apparatus & 20 & 11.5 & 1.2 & 0.97 & 102 & -2.7 & -0.8 \\
\hline
\end{tabular}

Source: Authors' calculations based on sources given in Appendix I.

Note: For the calculation of the measures, see text and Appendix II. SITC code numbers refer to Standard International Trade Classification, Revision 2. 
Table $1 b$

The 20 most dynamic products in world non-fuel exports, ranked by average annual export value growth, 1996-1998

\begin{tabular}{|c|c|c|c|c|c|c|c|c|}
\hline \multirow[b]{2}{*}{$\begin{array}{l}\text { SITC } \\
\text { code }\end{array}$} & \multirow[b]{2}{*}{ Product group } & \multicolumn{3}{|c|}{$1996-98$} & \multicolumn{4}{|c|}{$1980-98$} \\
\hline & & Rank & $\begin{array}{c}\text { Average } \\
\text { annual export } \\
\text { value growth } \\
\text { (Per cent) }\end{array}$ & $\begin{array}{c}\text { Average } \\
\text { annual growth of } \\
\text { share in world } \\
\text { non-fuel export } \\
\text { (Per cent) }\end{array}$ & Rank & $\begin{array}{l}\text { Average } \\
\text { annual export } \\
\text { value growth } \\
\text { (Per cent) }\end{array}$ & $\begin{array}{c}\text { Average } \\
\text { annual growth of } \\
\text { share in world } \\
\text { non-fuel exports } \\
\text { (Per cent) }\end{array}$ & $\begin{array}{l}\text { Stability } \\
\text { indicator }\end{array}$ \\
\hline 681 & Silver and platinum & 1 & 55.3 & 36.9 & 206 & 1.9 & 0.2 & 0.14 \\
\hline 714 & Non-electric engines and motors & 2 & 39.1 & 29.5 & 52 & 9.7 & 0.6 & 0.96 \\
\hline 792 & Aircraft and associated equipment & 3 & 38.4 & 29.2 & 78 & 8.7 & 1.7 & 0.90 \\
\hline 871 & Optical instruments & 4 & 37.6 & 28.8 & 4 & 14.1 & 0.1 & 0.99 \\
\hline 791 & Railway vehicles & 5 & 24.4 & 21.2 & 142 & 6.6 & 0.2 & 0.88 \\
\hline 075 & Spices & 6 & 18.2 & 17.1 & 171 & 4.8 & 0.0 & 0.85 \\
\hline 541 & Medicinal and pharmaceutical prod. & 7 & 15.8 & 15.3 & 19 & 11.6 & 1.2 & 0.98 \\
\hline 515 & Organo-inorganic compouds & 8 & 15.3 & 14.9 & 61 & 9.4 & 0.4 & 0.98 \\
\hline 289 & Precious metal ores, waste and scrap & 9 & 13.5 & 13.6 & 218 & -0.6 & 0.0 & 0.02 \\
\hline 244 & Cork, natural, raw and waste & 10 & 13.5 & 13.6 & 156 & 5.7 & 0.0 & 0.60 \\
\hline 514 & Nitrogen-function compounds & 11 & 13.0 & 13.3 & 22 & 11.2 & 0.5 & 0.97 \\
\hline 074 & Tea and mate & 12 & 12.5 & 12.9 & 205 & 2.8 & 0.1 & 0.64 \\
\hline 764 & Telecom equipment, and parts & 13 & 12.0 & 12.4 & 15 & 11.9 & 1.9 & 0.98 \\
\hline 042 & Rice & 14 & 11.9 & 12.4 & 179 & 4.4 & 0.2 & 0.57 \\
\hline 845 & Knitted outergarments & 15 & 11.7 & 12.3 & 45 & 9.9 & 0.7 & 0.92 \\
\hline 846 & Knitted undergarments & 16 & 11.2 & 11.8 & 7 & 13.1 & 0.4 & 0.96 \\
\hline 633 & Cork manufactures & 17 & 10.9 & 11.6 & 87 & 9.7 & 0.0 & 0.90 \\
\hline 091 & Margarine and shortening & 18 & 10.8 & 11.5 & 102 & 8.1 & 0.0 & 0.81 \\
\hline 551 & Essential oils and perfume & 19 & 10.1 & 10.9 & 54 & 9.7 & 0.1 & 0.96 \\
\hline 723 & Civil engineering equipment & 20 & 9.9 & 10.8 & 192 & 3.5 & 0.6 & 0.68 \\
\hline
\end{tabular}

Source: See table 1a.

Note: For the calculation of the measures, see text and Appendix II. 
Table 2

Shares of main exporters, developed and developing countries in world non-fuel export of the

20 most dynamic products (ranked by index of dynamism based on export values, 1980-1998), 1998

$$
\text { (Per cent) }
$$

\begin{tabular}{|c|c|c|c|c|}
\hline $\begin{array}{l}\text { SITC } \\
\text { code }\end{array}$ & Product group & $\begin{array}{c}\text { Share of } \\
\text { developed } \\
\text { countries }\end{array}$ & $\begin{array}{c}\text { Share of } \\
\text { developing } \\
\text { countries }\end{array}$ & Main exporting countries (shares) \\
\hline 776 & Transistors and semiconductors & 53 & 46 & United States (17), Japan (15), Singapore (10), Malaysia (7) \\
\hline 752 & Computers & 63 & 36 & United States (13), Singapore (13), Japan (10), Netherlands (9) \\
\hline 871 & Optical instruments & 69 & 30 & Japan (22), United States (17), Rep. of Korea (12), Germany (10), China (5), Hong Kong SAE (5) \\
\hline 759 & Parts of computers and office machines & 61 & 38 & United States (17), Japan (14), Singapore (9), Taiwan Prov. (7), Malaysia (6) \\
\hline 764 & Telecom equipment, and parts & 75 & 24 & United States (15), United Kingdom (9), Japan (9), Sweden (7) \\
\hline 714 & Non-electric engines and motors & 94 & 4 & United States (30), United Kingdom (23), France (11), Germany (9), Canada (5) \\
\hline 541 & Medicinal and pharmaceutical products & 91 & 8 & Germany (15), Switzerland (11), United Kingdom (10), United States (10) \\
\hline 781 & Passenger motor cars & 89 & 9 & Germany (22), Japan (18), Canada (11), France (7) \\
\hline 792 & Aircraft and associated equipment & 93 & 6 & United States (46), France (14), Germany (12), United Kingdom (8) \\
\hline 846 & Knitted undergarments & 40 & 57 & China (16), United States (8), Turkey (6), Italy (6), Mexico (5) \\
\hline 893 & Plastic materials & 75 & 23 & United States (14), Germany (13), China (7), Italy (7) \\
\hline 514 & Nitrogen-function compounds & 88 & 11 & Ireland (18), Germany (13), United States (11), Switzerland (8) \\
\hline 771 & Electric power machinery & 61 & 37 & United States (11), Germany (10), China (9), Japan (9) \\
\hline 553 & Perfumery and cosmetics & 88 & 10 & France (28), United States (12), United Kingdom (12), Germany (11) \\
\hline 772 & Electrical apparatus, switches etc & 73 & 24 & Germany (15), United States (14), Japan (13), France (7), United Kingdom (5), Mexico (4) \\
\hline 872 & Medical instruments and appliances & 87 & 12 & United States (27), Germany (12), United Kingdom (7), Japan (6), Ireland (6) \\
\hline 778 & Electrical machinery and apparatus & 74 & 23 & Japan (17), United States (13), Germany (13), United Kingdom (7), Mexico (6) \\
\hline 515 & Organo-inorganic \& heterocyclic compounds & 89 & 9 & Ireland (20), United States (12), United Kingdom (9), Germany (8), Japan (8) \\
\hline 821 & Furniture and parts thereof & 72 & 21 & Italy (16), United States (9), Germany (9), Canada (8), China (5) \\
\hline 773 & Electricity distributing equipment & 59 & 34 & Mexico (16), United States (14), Germany (9), Japan (6), France (4) \\
\hline
\end{tabular}

Source: See table 1a.

Note: See UNCTAD, Handbook of Statistics, table 4.4 for the main exporters of these products within the group of developing countries. 
Table 3

The 20 most dynamic products in world non-fuel exports, ranked by index of dynamism based on shares in total exports, 1980-1998

\begin{tabular}{rcl}
\hline Rank & SITC code & Product group \\
\hline 1 & 776 & Transistors and semiconductors \\
2 & 752 & Computers \\
3 & 764 & Telecommunications equipment and parts \\
4 & 759 & Parts of computers and office machines \\
5 & 541 & Medicinal and pharmaceutical products \\
6 & 871 & Optical instruments and apparatus \\
7 & 781 & Passenger motor cars \\
8 & 772 & Electrical apparatus, switches etc \\
9 & 714 & Non-electric engines and motors \\
10 & 893 & Plastic materials \\
& & \\
11 & 846 & Knitted undergarments \\
12 & 514 & Nitrogen-function compounds \\
13 & 778 & Electrical machinery and apparatus \\
14 & 681 & Silver and platinum \\
15 & 821 & Furniture and parts thereof \\
16 & 792 & Aircraft and associated equipment \\
17 & 771 & Electric power machinery \\
18 & 553 & Perfumery and cosmetics \\
19 & 872 & Medical instruments and appliances \\
20 & 773 & Electricity distributing equipment
\end{tabular}

Source: See table 1a.

Note: For the calculation of the measure, see text and Appendix II. 
Table 4

Predictability of annual export value growth, selected products, 1980-1998

\begin{tabular}{|c|c|c|c|c|}
\hline $\begin{array}{c}\text { Rank by } \\
\text { predict- } \\
\text { ability }\end{array}$ & $\begin{array}{l}\text { SITC } \\
\text { code } \\
\end{array}$ & Product group & $\begin{array}{c}\text { Rank by } \\
\text { index on } \\
\text { dynamism } \\
\text { based on } \\
\text { export values } \\
\end{array}$ & $\begin{array}{c}\text { Rank by } \\
\text { average annual } \\
\text { growth of share } \\
\text { in world non- } \\
\text { fuel exports } \\
\end{array}$ \\
\hline 1 & 792 & Aircraft and associated equipment & 8 & 6 \\
\hline 2 & 714 & Non-electric engines and motors & 6 & 30 \\
\hline 3 & 554 & Soap, cleansing and polishing preparations & 63 & 129 \\
\hline 4 & 725 & Paper and pulp mill machinery & 142 & 152 \\
\hline 5 & 728 & Specialized machinery and equipment & 79 & 14 \\
\hline 6 & 881 & Photographic apparatus and equipment & 112 & 115 \\
\hline 7 & 847 & Clothing accessories of textile fabrics & 31 & 163 \\
\hline 8 & 633 & Cork manufactures & 34 & 216 \\
\hline 9 & 273 & Stone, sand and gravel & 115 & 185 \\
\hline 10 & 742 & Pumps for liquids, liquid elevators, and parts & 78 & 82 \\
\hline 11 & 679 & Iron and steel castings, forgings and stampings & 53 & 186 \\
\hline 12 & 011 & Meat and edible meat offals, fresh, chilled or frozen & 146 & 21 \\
\hline 13 & 737 & Metalworking machinery, and parts & 129 & 135 \\
\hline 14 & 034 & Fish, fresh (live or dead), chilled or frozen & 77 & 70 \\
\hline 15 & 749 & Non-electric accessories of machinery & 51 & 18 \\
\hline 16 & 812 & Sanitary, plumbing, heating and lighting fixtures & 35 & 102 \\
\hline 17 & 743 & Pumps, compressors, fans and blowers & 61 & 42 \\
\hline 18 & 667 & Pearls, precious and semi-precious stones & 156 & 25 \\
\hline 19 & 621 & Materials of rubber (pastes, plates, sheets) & 41 & 169 \\
\hline 20 & 741 & Heating and cooling equipment, and parts & 86 & 30 \\
\hline 206 & 001 & Live animals for food & 177 & 111 \\
\hline 207 & 056 & Preserved and prepared vegetables & 153 & 158 \\
\hline 208 & 289 & Ores and concentrates of precious metals & 210 & 201 \\
\hline 209 & 628 & Rubber articles & 28 & 153 \\
\hline 210 & 711 & Steam and other vapour generating boilers, and parts & 170 & 182 \\
\hline 211 & 042 & Rice & 162 & 147 \\
\hline 212 & 271 & Crude certilizers & 218 & 184 \\
\hline 213 & 282 & Waste and scrap metal of iron or steel & 135 & 156 \\
\hline 214 & 263 & Cotton & 200 & 98 \\
\hline 215 & 047 & Other cereal meals and flours & 203 & 219 \\
\hline 216 & 071 & Coffee and coffee substitutes & 208 & 66 \\
\hline 217 & 211 & Raw hides and skins (except fur skins) & 193 & 157 \\
\hline 218 & 233 & Synthetic rubber & 198 & 151 \\
\hline 219 & 266 & Synthetic fibres suitable for spinning & 171 & 162 \\
\hline 220 & 524 & Radioactive and associated materials & 206 & 148 \\
\hline 221 & 037 & prepared or preserved fish, crustaceans and molluscs & 85 & 142 \\
\hline 222 & 045 & Unmilled cereals (other than wheat, rice, barley, maize) & 224 & 196 \\
\hline 223 & 251 & Pulp and waste paper & 186 & 56 \\
\hline 224 & 274 & Sulphur and unroasted iron pyrites & 213 & 202 \\
\hline 225 & 681 & Silver and platinum & 169 & 132 \\
\hline
\end{tabular}

Source: See table 1a.

Note: For the calculation of the measures, see text and Appendix II. 
Table 5

The 20 most dynamic products in world non-fuel exports ranked by composite index on predictability, volatility and growth, 1980-1998

\begin{tabular}{|c|c|c|c|c|}
\hline Rank & $\begin{array}{c}\text { SITC } \\
\text { code } \\
\end{array}$ & Product group & $\begin{array}{c}\text { Rank by } \\
\text { index on } \\
\text { dynamism } \\
\text { based on } \\
\text { export values }\end{array}$ & $\begin{array}{c}\text { Rank by index } \\
\text { on dynamism } \\
\text { based on } \\
\text { shares in total } \\
\text { exports } \\
\end{array}$ \\
\hline 1 & 846 & Knitted undergarments & 10 & 11 \\
\hline 2 & 714 & Non-electric engines and motors & 6 & 9 \\
\hline 3 & 752 & Computers & 2 & 2 \\
\hline 4 & 553 & Perfumery and cosmetics & 14 & 18 \\
\hline 5 & 048 & Cereal preparations & 33 & 42 \\
\hline 6 & 893 & Plastic articles & 11 & 10 \\
\hline 7 & 111 & Non-alcoholic beverages & 45 & 65 \\
\hline 8 & 847 & Textile clothing accessoris & 31 & 52 \\
\hline 9 & 773 & Electricity distributing equipment & 20 & 20 \\
\hline 10 & 612 & Leather manufactures & 29 & 70 \\
\hline 11 & 728 & Specialized machinery and equipment & 79 & 88 \\
\hline 12 & 778 & Electrical machinery and apparatus & 17 & 13 \\
\hline 13 & 655 & Knitted fabrics & 24 & 23 \\
\hline 14 & 872 & Medical instruments and appliances & 16 & 19 \\
\hline 15 & 821 & Furniture and parts thereof & 19 & 15 \\
\hline 16 & 759 & Parts of computers and office machines & 4 & 4 \\
\hline 17 & 592 & Starch, inulin, gluten, albuminoidal substances & 44 & 46 \\
\hline 18 & 062 & Non-chocolate sugar preparations & 72 & 86 \\
\hline 19 & 776 & Transistors and semiconductors & 1 & 1 \\
\hline 20 & 679 & Iron and steel castings & 53 & 54 \\
\hline
\end{tabular}

Source: See table 1a.

Note: For the calculation of the measures, see text and Appendix II. 


\section{Table 6}

Market-share concentration of dynamic products in world non-fuel exports identified on the basis of index of dynamism, based on export values, 1980-1998

\begin{tabular}{|c|c|c|c|c|c|c|c|}
\hline \multirow{2}{*}{$\begin{array}{c}\text { Rank by } \\
\text { index of } \\
\text { dynamism }\end{array}$} & \multirow[b]{2}{*}{$\begin{array}{c}\text { SITC } \\
\text { code }\end{array}$} & \multirow[b]{2}{*}{ Product group } & \multicolumn{5}{|c|}{ Index of market-share concentration } \\
\hline & & & $\begin{array}{c}1980- \\
1981 \\
\end{array}$ & $\begin{array}{r}1984- \\
1985 \\
\end{array}$ & $\begin{array}{c}1990- \\
1991 \\
\end{array}$ & $\begin{array}{r}1994- \\
1995 \\
\end{array}$ & $\begin{array}{r}1997- \\
1998 \\
\end{array}$ \\
\hline 1 & 776 & Transistors and semiconductors & 1285 & 1259 & 1163 & 1171 & 945 \\
\hline 2 & 752 & Computers & 1735 & 1350 & 1121 & 977 & 797 \\
\hline 3 & 871 & Optical instruments and apparatus & 1655 & 1629 & 1451 & 1362 & 1132 \\
\hline 4 & 759 & Parts of computers and office machines & 2055 & 1824 & 1028 & 986 & 858 \\
\hline 5 & 764 & Telecommunications equipment, and parts & 971 & 1219 & 1153 & 819 & 676 \\
\hline 6 & 714 & Non-electric engines and motors & 2306 & 2136 & 1919 & 1650 & 1733 \\
\hline 7 & 541 & Medicinal and pharmaceutical products & 891 & 886 & 827 & 767 & 771 \\
\hline 8 & 781 & Passenger motor cars & 1713 & 1818 & 1474 & 1214 & 1122 \\
\hline 9 & 931 & Special transactions and commodities & 2341 & 1540 & 954 & 724 & 709 \\
\hline 10 & 792 & Aircraft and associated equipment & 2994 & 2684 & 2524 & 2146 & 2463 \\
\hline 11 & 846 & Knitted under garments & 523 & 558 & 411 & 438 & 567 \\
\hline 12 & 893 & Plastic materials & 826 & 814 & 767 & 632 & 647 \\
\hline 13 & 514 & Nitrogen-function compounds & 1217 & 1190 & 1014 & 909 & 850 \\
\hline 14 & 771 & Electric power machinery & 931 & 849 & 748 & 609 & 566 \\
\hline 15 & 553 & Perfumery and cosmetics & 1601 & 1654 & 1481 & 1395 & 1249 \\
\hline 16 & 772 & Electrical apparatus & 1053 & 1033 & 1088 & 934 & 794 \\
\hline 17 & 872 & Medical instruments and appliances & 1115 & 1113 & 1224 & 1081 & 1123 \\
\hline 18 & 778 & Electrical machinery and apparatus & 1035 & 1140 & 1066 & 899 & 826 \\
\hline 19 & 515 & Organo-inorganic \& heterocyclic compounds & 1038 & 896 & 848 & 802 & 915 \\
\hline 20 & 821 & Furniture and parts thereof & 954 & 862 & 821 & 678 & 649 \\
\hline
\end{tabular}

Source: See table 1a.

Note: For the calculation of the measure, see text and Appendix II. The index of market-share concentration ranges between 43 , indicating that all countries in the sample have an equal share ( 0.43 per cent) in a product's total exports, and 10000 , indicating that the product is exported by only one country. 
Table 7

Shares of main exporters, developed and developing countries in world exports of the

most agricultural commodities (ranked by index of dynamism based on export values, 1980-1998), 1998

(Per cent)

\begin{tabular}{|c|c|c|c|c|c|c|}
\hline Rank & $\begin{array}{c}\text { SITC } \\
\text { code }\end{array}$ & $\begin{array}{c}\text { Rank } \\
\text { among all } \\
\text { products }\end{array}$ & Product group & $\begin{array}{c}\text { Share of } \\
\text { developed } \\
\text { countries }\end{array}$ & $\begin{array}{c}\text { Share of } \\
\text { developing } \\
\text { countries }\end{array}$ & Main exporting countries (shares) \\
\hline 1 & 048 & 32 & Cereal preparations & 84 & 14 & Italy (11), Germany (10), France (10), United Kingdom (8) \\
\hline 2 & 111 & 43 & Non-Alcoholic beverages & 75 & 22 & France (19), Canada (7), United States (7), Belgium/Luxembourg (7) \\
\hline 3 & 098 & 49 & Edible products and preparations & 80 & 17 & United States (16), France (12), Germany (8), China (5), Netherlands (6) \\
\hline 4 & 062 & 67 & Non-chocolate sugar preparations & 69 & 25 & United Kingdom (10, Germany (9), Spain (9), United States (7), Belgium/Luxembourg (6) \\
\hline 5 & 122 & 69 & Manufactured tobacco & 74 & 24 & United States (29), Netherlands (16), United Kingdom (10) \\
\hline 6 & 034 & 75 & Fish, fresh, chilled frozen & 61 & 37 & Norway (13), United States (7), Denmark (5), China (5), Taiwan Province of China (5), Chile (5) \\
\hline 7 & 037 & 80 & Fish, prepared, preserved & 40 & 58 & Thailand (20), China (10), Denmark (5), Spain (4), Germany (4) \\
\hline 8 & 036 & 84 & Shell fish, fresh, frozen & 15 & 70 & Thailand (12), Indonesia (7), Canada (6), India (6), Ecuador (6) \\
\hline 9 & 112 & 86 & Alcoholic beverages & 87 & 10 & France (28), United Kingdom (16), Italy (10), Spain (6) \\
\hline 10 & 073 & 88 & Chocolate & 88 & 7 & Germany (16), Belgium/Luxembourg (13), France (11), United Kingdom (8) \\
\hline 11 & 269 & 93 & Waste of textile fabrics & 82 & 16 & United States (22), Germany (15), United Kingdom (8), Netherlands (8) \\
\hline 12 & 054 & 95 & Vegetables, fresh, simply pres. & 67 & 31 & Netherlands (15), Spain (12), United States (9), Mexico (9), Italy (7) \\
\hline 13 & 091 & 96 & Margarine and shortening & 71 & 25 & Germany (16), Netherlands (11), Belgium/Luxembourg (11), United States (7) \\
\hline 14 & 245 & 97 & Fuel wood and charcoal & 24 & 41 & Latvia (15), Indonesia (10), China (10), France (6), Poland (5) \\
\hline 15 & 058 & 104 & Fruit, preserved, prepared & 57 & 37 & Brazil (11), United States (9), Germany (7), Belgium/Luxembourg (6), Italy (6) \\
\hline 16 & 292 & 111 & Crude vegetable materials & 74 & 25 & Netherlands (31), United States (7), Germany (5), Italy (5), Denmark (5) \\
\hline 17 & 423 & 115 & Soft fixed vegetable oils & 59 & 38 & Argentina (21), United States (11), Spain (10), Germany (7), Brazil (7) \\
\hline 18 & 057 & 116 & Fruits, nuts, fresh, dried & 58 & 41 & Spain (13), United States (12), Italy (7), Belgium/Luxembourg (6), France (5) \\
\hline 19 & 014 & 121 & Meat, prepared, preserved & 68 & 23 & Denmark (10), Belgium/Luxembourg (10), United States (9), France (9) \\
\hline 20 & 431 & 122 & Processed animal and vegetable oil & 51 & 48 & Malaysia (25), Netherlands (12), Germany (10), Indonesia (10) \\
\hline 21 & 024 & 123 & Cheese and curd & 95 & 2 & France (19), Netherlands (18), Germany (15), Denmark (9), Italy (7) \\
\hline 22 & 291 & 126 & Crude animal materials & 56 & 40 & China (18), Germany (10), United States (10), Taiwan Province of China. (6), Netherlands (5) \\
\hline 23 & 022 & 133 & Milk and cream & 89 & 7 & Germany (22), France (14), Netherlands (10), Belgium/Luxembourg (9) \\
\hline 24 & 011 & 145 & Meat, fresh, chilled or frozen & 79 & 17 & United States (16), Netherlands (10), France (9), Denmark (7), Australia (7) \\
\hline 25 & 075 & 148 & Spices & 22 & 77 & Singapore (13), Indonesia (12), India (11), China (6), Netherlands (5) \\
\hline
\end{tabular}

Source: See table 1a.

Note: See UNCTAD, Handbook of Statistics, table 4.4 for the main exporters of these products within the group of developing countries. Bold characters indicate high-value products and/or items with an income elasticity of demand greater than one (see Appendix III.(iii)). 
Table 8

Leading dynamic products by exporting region, ranked by average annual export value growth, 1980-1998

\begin{tabular}{|c|c|c|}
\hline \multicolumn{3}{|c|}{$\begin{array}{c}\text { SITC } \\
\text { Rank code Product group }\end{array}$} \\
\hline \multicolumn{3}{|c|}{ Developed countries } \\
\hline 1 & 776 & Transistors and semiconductors \\
\hline 2 & 844 & Textile undergarments \\
\hline 3 & 553 & Perfumery and cosmetics \\
\hline 4 & 871 & Optical instruments \\
\hline 5 & 752 & Computers \\
\hline 6 & 893 & Plastic articles \\
\hline 7 & 759 & Parts of computers $\&$ office machines \\
\hline 8 & 898 & Musical instruments and records \\
\hline 9 & 541 & Medicinal \& pharmaceutical products \\
\hline 10 & 846 & Knitted undergarments \\
\hline 11 & 872 & Medical instruments \\
\hline 12 & 048 & Cereal preparations \\
\hline 13 & 111 & Non-alcoholic beverages \\
\hline 14 & 764 & Telecom equipment, and parts \\
\hline 15 & 771 & Electric power machinery \\
\hline 16 & 783 & Road motor vehicles nes \\
\hline 17 & 098 & Edible products and preparations \\
\hline 18 & 514 & Nitrogen-function compounds \\
\hline 19 & 873 & Meters and counters \\
\hline 20 & 073 & Chocolate \\
\hline
\end{tabular}

\section{First-tier NIEs}

1752 Computers

$2 \quad 277$ Natural abrasives

3783 Road motor vehicles nes

4951 War firearms and ammunition

5871 Optical instruments

6592 Starch, inulin, gluten, albuminoidal sub.

7781 Passenger motor vehicles, excl buses

8611 Leathe

$9 \quad 212$ Raw furskins

10582 Condensation products

11882 Photographic \& cinematographic supplies

12682 Copper

13759 Parts of computers \& office machines

14686 Zinc

15513 Carboxylic acids

16524 Radioactive materials

17122 Manufactured tobacco

18712 Steam engines and turbines

19774 Medical apparatus

20515 Organo-inorganic compounds

\section{South Asia}

1761 Television receivers

2752 Computers

3582 Condensation products

4674 Iron or steel universals, plates and sheets

5515 Organo-inorganic compounds

$6 \quad 655$ Knitted fabrics

7266 Synthetic fibres for spinning

8672 Iron or steel ingots and forms

9871 Optical instruments

10759 Parts of computers \& office machines

11673 Iron or steel bars and rods

12513 Carboxylic acids

13661 Lime, cement and building products

14583 Polymerization products

15514 Nitrogen-function compounds

$16 \quad 277$ Natural abrasives

17511 Hydrocarbons

$18 \quad 683$ Nickel

19898 Musical instruments and records

20781 Passenger motor vehicles, excl buses

$\begin{array}{ll}\text { SITC } & \text { SITC } \\ \text { code Product group } & \text { code Product group }\end{array}$

\section{Developing countries}

\section{Computers}

871 Optical instruments

582 Corts of computers \& office machines

582 Condensation products

741 Heating and cooling equipment

655 Knitted fabrics

531 Synthetic organic dyestuffs

773 Electricity distributing equipment

712 Steam engines and turbines

781 Passenger motor vehicles, excl buses

872 Medical instruments

763 Sound recorders

583 Polymerization products

776 Transistors and semiconductors

771 Electric power machinery

679 Iron and steel castings

774 Medical apparatus

592 Starch, inulin, gluten, albuminoidal sub.

516 Other organic chemicals

761 Television receivers

Developing Asia excluding West Asia, ASEAN-4 (Indonesia, Malaysia,

Central Asia, 1st-tier NIEs and China Philippines, Thailand)

752 Computers

759 Parts of computers and office machines

763 Sound recorders

672 Iron or steel ingots and forms

761 Television receivers

751 Office machines

674 Iron or steel universals, plates and sheets

871 Optical instruments

716 Rotating electric plant, and parts

511 Hydrocarbons

277 Natural abrasives

582 Condensation products

267 Other man-made fibres

764 Telecom equipment, and parts

592 Starch, inulin, gluten, albuminoidal sub

641 Paper and paperboard

781 Passenger motor vehicles, excl buses

773 Electricity distributing equipment

881 Photographic apparatus \& equipment nes

677 Iron or steel wire

\section{Central America and the Caribbean}

851 Footwear

265 Vegetable fibres, excl cotton \& jute

778 Electrical machinery $\&$ apparatus

266 Synthetic fibres for spinning

268 Wool and animal hair

411 Animal oils and fats

678 Iron or steel tubes and pipes

751 Office machines

759 Parts of computers \& office machine

772 Electrical apparatus, switches etc

874 Measuring \& controlling instruments

671 Pig iron

785 Cycles, motorized or not

245 Fuel wood and charcoal

871 Optical instruments

582 Condensation products

872 Medical instrument

742 Pumps for liquids

737 Metal working machinery

724 Textile and leather machinery

\section{Developing countries excl. 1st-tier NIEs}

871 Optical instruments

759 Parts of computers \& office machines

761 Television receivers

881 Photogr apparatus and equipment

752 Computers

655 Knitted fabrics

894 Toys and sporting goods

762 Radio receivers

898 Musical instruments and records

885 Watches and clocks

893 Plastic articles

666 Pottery

895 Office supplies nes

679 Iron and steel castings

773 Electricity distributing equipment

785 Cycles, motorized or not

741 Heating and cooling equipmen

831 Travel goods and handbags

531 Synthetic organic dyestuffs

Computers

759 Parts of computers \& office machines

871 Optical instruments

763 Sound recorders

672 Iron or steel ingots and forms

751 Office machines

716 Rotating electric plant

511 Hydrocarbons

277 Natural abrasives

761 Television receivers

785 Cycles, motorized or not

773 Electricity distributing equipment

267 Other man-made fibres

786 Trailers and other non-motor vehicles

775 Household equipment

641 Paper and paperboard

592 Starch, inulin, gluten, albuminoidal sub

677 Iron or steel wire

781 Passenger motor vehicles, excl buses

268 Wool and animal hair

\section{South America}

245 Fuel wood and charcoa

682 Copper

292 Crude vegetable materials

098 Edible products preparations

014 Meat prepared or preserved

121 Unmanufactured tobacco

524 Radioactive materials

716 Rotating electric plant

678 Iron or steel tubes, pipes and fittings

812 Plumbing, heating \& lighting equipment

523 Other inorganic chemicals

111 Non-alcoholic beverages

845 Knitted outergarments

951 War firearms and ammunition

713 Internal combustion piston engines \& parts

045 Unmilled cereals

671 Pig iron

046 Wheat meal or flour

551 Essential oils and perfume

655 Knitted fabrics

Source: See table 1a.

Note: For the calculation of the measures, see text and Appendix II. The product groups highlighted are among the 20 most dynamic ones on a world scale, as listed in table 1a. 
Table 9

Composition of non-fuel exports, selected developing countries, 1996-1998 averages

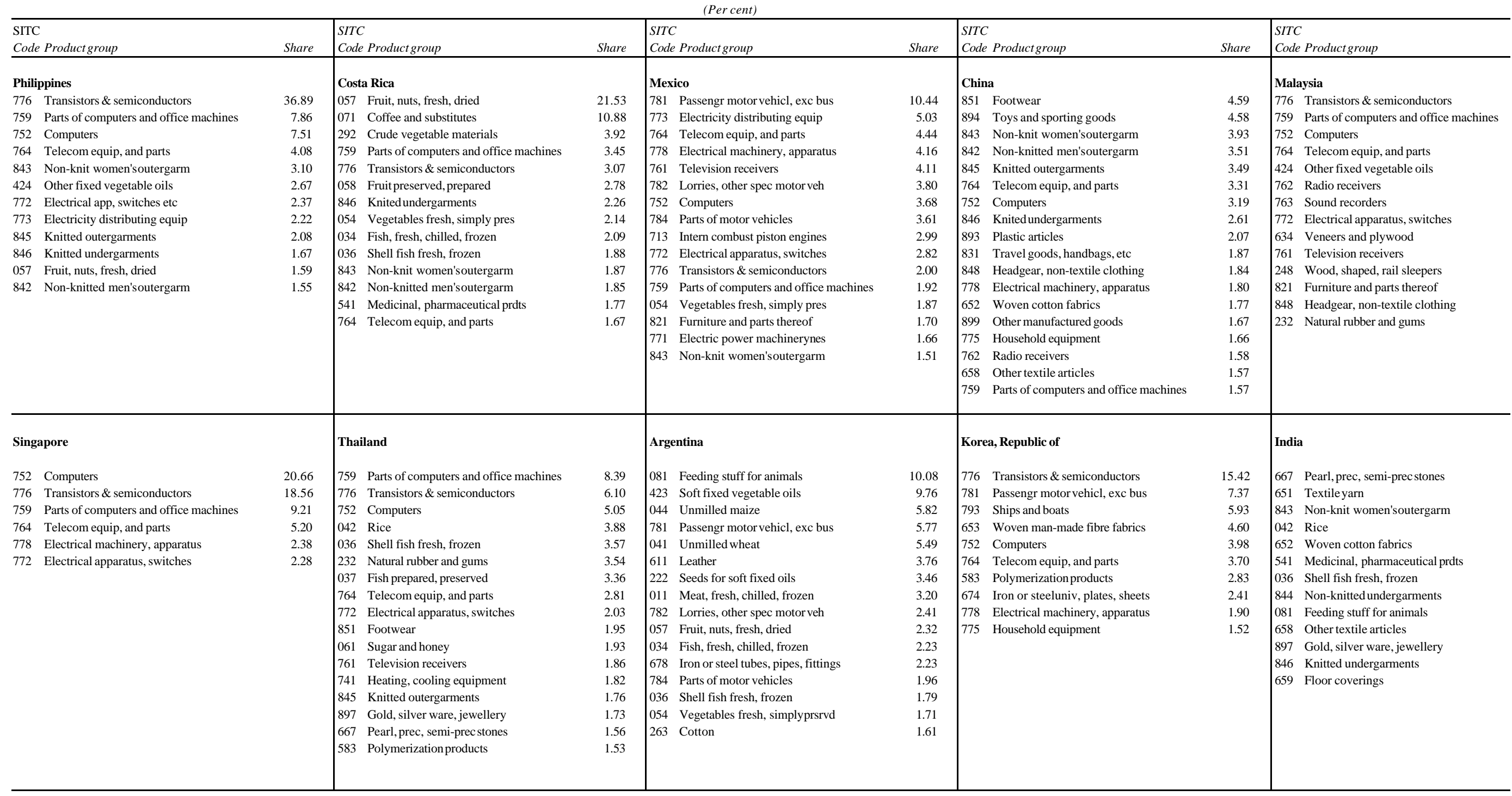

Source: See table la.

Notes: Share refers to a product's average share in an economy's total merchandise exports during the period 1996-1998. For each of the countries, all products with a share of at least 1.5 per cent are included. The economies are ordered according to their aver 
Table 9 (concluded)

Composition of non-fuel exports, selected developing countries, 1996-1998 averages

\begin{tabular}{|c|c|c|c|c|c|c|c|c|c|c|c|c|}
\hline \multirow{2}{*}{\multicolumn{2}{|c|}{$\overline{S I T C}$}} & \multirow{2}{*}{\multicolumn{3}{|c|}{ SITC }} & & (Percent) & & & & \multirow{2}{*}{\multicolumn{3}{|c|}{ SITC }} \\
\hline & & & & & \multicolumn{3}{|c|}{ SITC } & \multicolumn{2}{|l|}{ SITC } & & & \\
\hline Code Product group & Share & \multicolumn{2}{|c|}{ Code Product group } & Share & \multicolumn{2}{|c|}{ Code Product group } & Share & Code Product group & Share & \multicolumn{2}{|c|}{ Code Product group } & Share \\
\hline Morocco & & Peru & & & Turl & & & China, Hong Kong SAR & & Chile & & \\
\hline 522 Inorganic chemical elements & 11.99 & 682 & Copper & 18.06 & & Knitted outergarments & 8.48 & 845 Knitted outergarments & 12.62 & 682 & Copper & 30.50 \\
\hline 271 Crude fertilizers & 8.47 & 287 & Base metals ores, conc nes & 14.12 & 843 & Non-knit women's outergarm & 5.34 & 776 Transistors \& semiconductors & 9.20 & 057 & Fruit, nuts, fresh, dried & 7.06 \\
\hline 562 Manufactured fertilizers & 7.92 & 071 & Coffee and substitutes & 6.01 & 057 & Fruit, nuts, fresh, dried & 4.85 & 842 Non-knitted men's outergarm & 5.14 & 034 & Fish, fresh, chilled, frozen & 5.61 \\
\hline 057 Fruit, nuts, fresh, dried & 6.51 & 686 & Zinc & 4.06 & 673 & Iron or steel bars and rodes & 4.78 & 885 Watches and clocks & 4.67 & 251 & Pulp and waste paper & 4.81 \\
\hline 845 Knitted outergarments & 5.64 & 846 & Knited undergarments & 3.71 & 658 & Textile articles nes & 3.05 & 759 Parts of computers and office machines & 4.08 & 081 & Feeding stuff for animals & 3.54 \\
\hline 842 Non-knitted men's outergarm & 5.23 & 681 & Silver and platinum & 3.04 & 651 & Textile yarn & 2.49 & 764 Telecom equip, and parts & 3.94 & 112 & Alcoholic beverages & 2.87 \\
\hline 037 Fish prepared, preserved & 3.80 & 036 & Shell fish fresh, frozen & 2.19 & 842 & Non-knitted men's outergarm & 2.31 & 846 Knited undergarments & 3.38 & & & \\
\hline 056 Vegetables preserved, prep & 2.69 & 056 & Vegetables preserved, prep & 2.01 & 653 & Woven man-made fibre fabrics & 2.22 & 897 Gold, silver ware, jewellery & 3.25 & & & \\
\hline 287 Base metals ores, conc nes & 2.33 & 845 & Knitted outergarments & 1.89 & 121 & Unmanufactured tobacco & 2.18 & 652 Woven cotton fabrics & 3.08 & & & \\
\hline 846 Knited undergarments & 2.10 & 281 & Iron ore and concentrates & 1.75 & 761 & Television receivers & 1.75 & 892 Printed matter & 2.30 & & & \\
\hline 034 Fish, fresh, chilled, frozen & 2.06 & 651 & Textile yarn & 1.71 & 652 & Woven cotton fabrics & 1.71 & 772 Electrical apparatus, switches & 2.25 & & & \\
\hline 843 Non-knit women's outergarm & 1.78 & 054 & Vegetables fresh, simply prsrvd & 1.51 & 773 & Electricity distributing equip & 1.53 & 583 Polymerization products & 2.11 & & & \\
\hline 773 Electricity distributing equip & 1.71 & & & & 848 & Headgear, non-textile clothing & 1.52 & 871 Optical instruments & 1.87 & & & \\
\hline 851 Footwear & 1.62 & & & & & & & & & & & \\
\hline 292 Crude vegetable materials & 1.52 & & & & & & & & & & & \\
\hline Indonesia & & \multicolumn{2}{|c|}{ Colombia } & & \multicolumn{2}{|c|}{ Taiwan, Province of China } & & Tunisia & & \multicolumn{2}{|c|}{ Brazil } & \\
\hline 634 Veneers and plywood & 9.65 & 071 & Coffee and substitutes & 27.97 & 752 & Computers & 10.11 & 842 Non-knitted men's outergarm & 21.55 & 281 & Iron ore and concentrates & 6.19 \\
\hline 287 Base metals ores, conc nes & 5.07 & 292 & Crude vegetable materials & 7.43 & 776 & Transistors \& semiconductors & 9.21 & 843 Non-knit women's outergarm & 12.19 & 071 & Coffee and substitutes & 5.52 \\
\hline 851 Footwear & 4.63 & 057 & Fruit, nuts, fresh, dried & 6.71 & 759 & Parts of computers and office machines & 8.01 & 562 Manufactured fertilizers & 5.94 & 081 & Feeding stuff for animals & 5.36 \\
\hline 424 Other fixed vegetable oils & 4.59 & 061 & Sugar and honey & 3.52 & 764 & Telecom equip, and parts & 3.41 & 846 Knited undergarments & 5.07 & 222 & Seeds for soft fixed oils & 3.92 \\
\hline 232 Natural rubber and gums & 4.40 & 583 & Polymerization products & 3.17 & 772 & Electrical apparatus, switches & 2.78 & 522 Inorganic chemical elements & 4.74 & 061 & Sugar and honey & 3.77 \\
\hline 036 Shell fish fresh, frozen & 3.10 & 591 & Pesticides and disinfectants & 2.44 & 653 & Woven man-made fibre fabrics & 2.65 & 845 Knitted outergarments & 4.31 & 784 & Parts of motor vehicles & 3.61 \\
\hline 641 Paper and paperboard & 2.97 & 541 & Medicinal, pharmaceutical prdts & 2.23 & 785 & Cycles, motorized or not & 2.49 & 773 Electricity distributing equip & 4.25 & 672 & Iron or steel ingots and forms & 3.50 \\
\hline 897 Gold, silver ware, jewellery & 2.94 & 671 & Pig iron & 2.08 & 893 & Plastic articles & 2.49 & 423 Soft fixed vegetable oils & 3.74 & 851 & Footwear & 3.12 \\
\hline 653 Woven man-made fibre fabrics & 2.85 & 846 & Knited undergarments & 1.92 & 655 & Knitted fabrics & 2.44 & 844 Non-knitted undergarments & 2.80 & 058 & Fruit preserved, prepared & 2.80 \\
\hline 651 Textile yarn & 2.53 & 667 & Pearl, prec, semi-prec stones & 1.85 & 778 & Electrical machinery, apparatus & 2.38 & 612 Leather manufactures & 2.48 & 011 & Meat, fresh, chilled, frozen & 2.65 \\
\hline 843 Non-knit women's outergarm & 2.46 & 842 & Non-knitted men's outergarm & 1.84 & 699 & Base metal manufactures & 2.34 & 851 Footwear & 2.17 & 684 & Aluminium & 2.62 \\
\hline 842 Non-knitted men's outergarm & 2.09 & 892 & Printed matter & 1.50 & 657 & Spec textile fabrics \& products & 2.16 & 772 Electrical apparatus, switches & 2.08 & 781 & Passengr motor vehicl, exc bus & 2.57 \\
\hline 763 Sound recorders & 2.07 & & & & & Polymerization products & 2.14 & 523 Other inorganic chemicals & 1.59 & 713 & Intern combust piston engines & 2.33 \\
\hline 635 Wood manufactures & 2.02 & & & & 894 & Toys and sporting goods & 2.14 & 036 Shell fish fresh, frozen & 1.51 & 251 & Pulp and waste paper & 2.17 \\
\hline 821 Furniture and parts thereof & 1.99 & & & & 651 & Textile yarn & 1.87 & & & 121 & Unmanufactured tobacco & 2.16 \\
\hline 764 Telecom equip, and parts & 1.93 & & & & 771 & Electric power machinery & 1.61 & & & 641 & Paper and paperboard & 1.92 \\
\hline 071 Coffee and substitutes & 1.73 & & & & 728 & Oth machy for spec industries & 1.53 & & & 671 & Pig iron & 1.86 \\
\hline 759 Parts of computers and office machines & 1.65 & & & & 674 & Iron or steel univ, plates, sheets & 1.50 & & & 792 & Aircraft & 1.79 \\
\hline 251 Pulp and waste paper & 1.61 & & & & & & & & & 782 & Lorries, other spec motor veh & 1.73 \\
\hline 845 Knitted outergarments & 1.52 & & & & & & & & & 674 & Iron or steel univ, plates, sheets & 1.73 \\
\hline & & & & & & & & & & 423 & Soft fixed vegetable oils & 1.53 \\
\hline
\end{tabular}


Table 10

Dynamic products in non-fuel imports of developing countries,

by average annual import value growth, 1988-1998

\begin{tabular}{|c|c|c|c|c|c|c|}
\hline \multirow{4}{*}{$\begin{array}{l}\text { SITC } \\
\text { code }\end{array}$} & \multirow[b]{4}{*}{ Product group } & \multirow{4}{*}{$\begin{array}{c}\text { Average annual } \\
\text { import value } \\
\text { growth, } \\
\text { 1988-1998 } \\
\text { (Per cent) } \\
\text { (1) } \\
\end{array}$} & \multicolumn{3}{|c|}{ Share in total imports } & \multirow{4}{*}{$\begin{array}{c}\text { Rank by } \\
\text { average annual } \\
\text { export value } \\
\text { growth } \\
1988-1998 \\
\text { (5) }\end{array}$} \\
\hline & & & 1990 & 1995 & 1998 & \\
\hline & & & \multicolumn{3}{|c|}{ (Index numbers, $1988=100)$} & \\
\hline & & & (2) & $(3)$ & (4) & \\
\hline 871 & Optical instruments & 25.3 & 146 & 670 & 940 & 1 \\
\hline 941 & Zoo animals and pets & 21.0 & 127 & 451 & 612 & 125 \\
\hline 776 & Transistors and semiconductors & 19.5 & 121 & 437 & 518 & 6 \\
\hline 759 & Parts of computers and office machines & 19.1 & 139 & 412 & 546 & 2 \\
\hline 893 & Plastic articles & 18.6 & 158 & 485 & 559 & 78 \\
\hline 846 & Knitted undergarments & 17.6 & 187 & 499 & 582 & 69 \\
\hline 851 & Footwear & 17.4 & 192 & 559 & 479 & 194 \\
\hline 771 & Electric power machinery nes & 17.1 & 133 & 370 & 449 & 16 \\
\hline 752 & Computers & 17.0 & 141 & 354 & 453 & 14 \\
\hline 612 & Leather manufactures & 16.8 & 209 & 508 & 523 & 164 \\
\hline 844 & Non-knitted undergarments & 16.1 & 165 & 417 & 490 & 137 \\
\hline 764 & Telecom equipment and parts & 16.0 & 140 & 385 & 407 & 28 \\
\hline 845 & Knitted outergarments & 15.6 & 144 & 344 & 467 & 171 \\
\hline 773 & Electricity distributing equipment & 15.4 & 141 & 346 & 396 & 7 \\
\hline 681 & Silver and platinum & 15.4 & 194 & 372 & 453 & 70 \\
\hline 699 & Base metal manufactures & 15.4 & 130 & 324 & 399 & 55 \\
\hline 289 & Precious metal ores \& waste & 15.3 & 167 & 267 & 463 & 217 \\
\hline 772 & Electrical apparatus, switches etc & 15.0 & 121 & 306 & 366 & 9 \\
\hline 778 & Electrical machinery \& apparatus & 15.0 & 131 & 340 & 365 & 10 \\
\hline 951 & War firearms and ammunition & 15.0 & 162 & 298 & 448 & 11 \\
\hline
\end{tabular}

Source: See table 1a.

Note: For the calculation of the measures, see text and Appendix II. 


\section{REFERENCES}

Arndt SW and Kierzkowski H, eds. (2001). Fragmentation: New Production Patterns in the World Economy. Oxford: Oxford University Press.

Choudhri EU and Hakura DS (2000). International trade and productivity growth: Exploring the sectoral effects for developing countries. IMF Staff Papers, 47: 30-53. Washington, DC, International Monetary Fund.

Duttagupta R and Spilimbergo A (2000). What happened to Asian exports during the crisis? Working Paper WP/00/200. Washington, DC, International Monetary Fund, December.

ECE (1995). Economic Bulletin for Europe, 47, (United Nations publication, sales no. E.95.II.E.24. New York and Geneva, Economic Commission for Europe.

Ernst D and Guerrieri P (1998). International production networks and changing trade patterns in East Asia: The case of the electronics industry. Oxford Development Studies, 26(2): 191-212.

Gereffi G (1999). International trade and industrial upgrading in the apparel commodity chain. Journal of International Economics, 48: 37-70.

Gordon RJ (2000). Does the 'New Economy' measure up to the great inventions of the past? Journal of Economic Perspectives, 14: 49-79.

Hummels D, Ishii J and Yi KM (2001). The nature and growth of vertical specialization in world trade. Journal of International Economics, 54: 75-96.

Hummels D, Rapoport D and Yi KM (1998). Vertical specialization and the changing nature of world trade. Economic Policy Review. New York, Federal Reserve Bank, June: 79-99.

International Trade Centre UNCTAD/WTO (ITC) (1999). Tools for Strategic Market Research. United Nations: Geneva, November.

Jaffee S and Gordon P (1993). Exporting high-value food commodities: Success stories from developing countries. Discussion Paper, 198. Washington, DC, World Bank.

Lall S (1998). Exports of manufactures by developing countries: Emerging patterns of trade and location. Oxford Review of Economic Policy, 14(2): 54-73.

Lall S (2000). The technological structure and performance of developing country manufactured exports, 1985-98. Oxford Development Studies, 28: 337-369.

Mayer J (2002). Intra-industry trade and dynamic products in the exports of developing countries. Mimeo. UNCTAD.

$\mathrm{Ng} \mathrm{F}$ and Yeats A (2001). Production sharing in East Asia: Who does what for whom and why? In Cheng LK and Kierzkowski H eds. Global Production and Trade in East Asia. Boston, Kluwer Academic Publishers.

Oliner SO and Sichel DE (2000). The resurgence of growth in the late 1990s: Is information technology the story? Journal of Economic Perspectives, 14: 3-22. 
Romijn H., Van Assouw R and Mortimore M, with Carrillo J, Lall S and Poapongsakorn N (2000). TNCs, industrial upgrading and competitiveness in the automotive industry in NAFTA, MERCOSUR and ASEAN. In UNCTAD, The Competitiveness Challenge: Transnational Corporations and Industrial Restructuring in Developing Countries. United Nations publications, sales no. E.00.II.D.35, New York and Geneva.

UNCTAD (1995). An Analysis of Trading Opportunities Resulting from the Uruguay Round in Selected Sectors: Agriculture, Textiles and Clothing, and Other Industrial Products. Document TD/B/WG.8/2. Geneva, June.

UNCTAD (1997). Ways and Means for Improving the Opportunities for the Expansion of Exports of Goods and Services from Developing Countries. Document TD/B/COM.1/13. Geneva, September.

UNCTAD (various issues). Handbook of International Trade and Development Statistics. United Nations. New York and Geneva.

UN/DESA (1999). 1997 International Trade Statistics Yearbook, Volume II: Trade by Commodity. Document ST/ESA/STAT/SER.G/46. New York, United Nations, Department of Economic and Social Affairs, Statistics Division.

United Nations Economic Commission for Latin America and the Caribbean (UNECLAC) and the World Bank (1999). TradeCAN: Database and Software for a Competitiveness Analysis of Nations. Santiago de Chile and Washington, DC.

USITC (1999). Production Sharing: The Use of U.S. Components and Materials in Foreign Assembly Operations, 1995-1998. USITC Publication, 3265. Washington, DC, United States International Trade Commission, December.

World Bank (1994). Global Economic Prospects and the Developing Countries. Washington, DC.

WTO (1998). Trade Policy Review: European Union 1997. Geneva, World Trade Organization.

Yeats A (2001). Just how big is global production sharing? In: Arndt SW and Kierzkowski H, eds. Fragmentation: New Production Patterns in the World Economy. Oxford, Oxford University Press. 


\section{UNCTAD Discussion Papers}

No. Date

94

95 January 1995

William W.F. Choa

96 February 1995

Alexandre R. Barros

97 February 1995

Ajit Singh

98 April 1995

99 May 1995

100 August 1995

Roberto Frenkel

101 August 1995

102 August 1995

103 September 1995

Toni Haniotis and Sebastian Schich

104 September 1995 Robert Rowthorn

105 October 1995 Giovanni N. De Vito

106 October $1995 \quad$ John Eatwell

107 November 1995 Luisa E. Sabater

108 November 1995 David Felix

109 December $1995 \quad$ Urvashi Zutshi

110 January 1996

H.A.C. Prasad

111 January 1996

Charles Gore
Title

Financial services in China

The derivation of trade matrices by commodity groups in current and constant prices

The role of wage stickiness in economic growth

How did East Asia grow so fast? Slow progress towards an analytical consensus

The role of the firm in the innovation process

Trade and labour standards: Using the wrong instruments for the right cause

Macroeconomic sustainability and development prospects: Latin American performance in the 1990s

Walking on two legs: Strengthening democracy and productive entrepreneurship in the transition economies

Financing the public sector in Latin America

Should governments subsidize exports through export credit insurance agencies?

A simulation model of North-South trade

Market distortions and competition: The particular case of Malaysia

Disguised unemployment: The G7 experience

Multilateral debt of least developed countries

Financial globalization versus free trade: The case for the Tobin tax

Aspects of the final outcome of the negotiations on financial services of the Uruguay Round

Bilateral terms of trade of selected countries from the South with the North and the South

Methodological nationalism and the misunderstanding of East Asian industrialization 
112 March 1996

113 March 1996

114 April 1996

115 April 1996

116 June 1996

117 August 1996

118 September 1996

119 September 1996

120 October 1996

121 October 1996

122 December 1996

123 December 1996

124 March 1997

$125 \quad$ April 1997

$126 \quad$ April 1997

$127 \quad$ May 1997

$128 \quad$ September 1997

129 September 1997
Enrique Cosio-Pascal

Djidiack Faye

Paul Bairoch and

Richard Kozul-Wright

Rameshwar Tandon

E.V.K. Fitzgerald

Jussi Lankoski

José Ripoll

Sunanda Sen

Leena Alanen

Sinan Al-Shabibi

Jean-François Outreville

Jörg Mayer

L. Rutten and

L. Santana-Boado

Jörg Mayer

Brigitte Bocoum

Jussi Lankoski

Raju Jan Singh

Andrew J. Cornford
Aide publique au développement et dette extérieure: Quelles mesures opportunes pour le financement du secteur privé en Afrique?

Globalization myths: Some historical reflections on integration, industrialization and growth in the world economy

Japanese financial deregulation since 1984

Intervention versus regulation: The role of the IMF in crisis prevention and management

Controlling agricultural nonpoint source pollution: The case of mineral balances

Domestic insurance markets in developing countries: Is there any life after GATS?

Growth centres in South East Asia in the era of globalization

The impact of environmental cost internalization on sectoral competitiveness: A new conceptual framework

Structural adjustment for the transition to disarmament: An assessment of the role of the market

Reinsurance in developing countries: Market structure and comparative advantage

Implications of new trade and endogenous growth theories for diversification policies of commoditydependent countries

Collateralized commodity financing with special reference to the use of warehouse receipts

Is having a rich natural-resource endowment detrimental to export diversification?

The new mining legislation of Côte d'Ivoire: Some comparative features

Environmental effects of agricultural trade liberalization and domestic agricultural policy reforms

Banks, growth and geography

Debt sustainability and social and human development: The net transfer approach and a comment on the so-called "net" present value calculation for debt relief

Selected features of financial sectors in Asia and their implications for services trade 
130 March 1998

Matti Vainio

131 Feb./March 1998

Roberth Rowthorn and Richard Kozul-Wright

132 March 1998

133 March 1998

134 April 1998

135 May 1998

136 June 1998

137 June 1998

138 October 1998

139 December 1998

140 February 1999

141 May 1999

142 November 1999

143 November 1999

144 December 1999

145 January 2000

146 February 2000

147 April 2000
Martin Brownbridge

Rubens Lopes Braga

A.V. Ganesan

Jene K. Kwon

Jomo K.S. and M. Rock

Rajah Rasiah

Zeljka Kozul-Wright and Lloyds Stanbury

Mehdi Shafaeddin

M. Branchi, G. Gabriele and V. Spiezia

Lorenza Jachia and Ethél Teljeur

Jean-François Outreville

Yilmaz Akyüz and

Andrew Cornford

Wei Ge

B. Andersen, Z. Kozul-Wright and R. Kozul-Wright

Manuel R. Agosin

and Ricardo Mayer

Martin Khor
The effect of unclear property rights on environmental degradation and increase in poverty

Globalization and economic convergence: An assessment

The causes of financial distress in local banks in Africa and implications for prudential policy

Expanding developing countries' exports in a global economy: The need to emulate the strategies used by transnational corporations for international business development

Strategic options available to developing countries with regard to a Multilateral Agreement on Investment

The East Asian Model: An exploration of rapid economic growth in the Republic of Korea and Taiwan Province of China

Economic diversification and primary commodity processing in the second-tier South-East Asian newly industrializing countries

The export manufacturing experience of Indonesia, Malaysia and Thailand: Lessons for Africa

Becoming a globally competitive player: The case of the music industry in Jamaica

How did developed countries industrialize? The history of trade and industrial policy: The cases of Great Britain and the USA

Traditional agricultural exports, external dependency and domestic prices policies: African coffee exports in a comparative perspective

Free trade between South Africa and the European Union - A quantitative analysis

Financial development, human capital and political stability

Capital flows to developing countries and the reform of the international financial system

The dynamics of export-processing zones

Copyrights, competition and development: The case of the music industry

Foreign investment in developing countries: Does it crowd in domestic investment?

Globalization and the South: Some critical issues 
148

149 July 2000

150 August 2000

151 October 2000

152 December 2000

153 December 2000

154 June 2001

155 August 2001

156 August 2001

157 September 2001

158 April 2002
Heiner Flassbeck

Yilmaz Akyüz

Mehdi Shafaeddin

Jörg Mayer

Bernard Shull

Dilip K. Das

Mehdi Shafaeddin

Jörg Mayer

Alberto Gabriele

Andrew J. Cornford

Yilmaz Akyüz and Korkut Boratav
The debate on the international financial architecture: Reforming the reformers

What did Frederick List actually say? Some clarifications on the infant industry argument

Globalization, technology transfer and skill accumulation in low-income countries

Financial modernization legislation in the United States - Background and implications

Asian crisis: Distilling critical lessons

Free trade or fair trade? Fallacies surrounding the theories of trade liberalization and protection and contradictions in international trade rules

Technology diffusion, human capital and economic growth in developing countries

Science and technology policies, industrial reform and technical progress in China: Can socialist property rights be compatible with technological catching up?

The Basel Committee's proposals for revised capital standards: Mark 2 and the state of play

The exchange rate: Economic policy tool or market price?

The making of the Turkish financial crisis

Copies of UNCTAD Discussion Papers may be obtained from the Publications Assistant, Macroeconomic and Development Policies Branch, GDS, UNCTAD, Palais des Nations, CH-1211 Geneva 10, Switzerland (Fax: (4122) 907.0274; E.mail: MDPB-Ed.Assistant@unctad.org). New Discussion Papers are available on the website at: http://www.unctad.org/en/pub/pubframe.htm 